National Water Availability and Use Program and National Water-Quality Assessment Program

\title{
Maps and Grids of Hydrogeologic Information Created from Standardized Water-Well Drillers' Records of the Glaciated United States
}

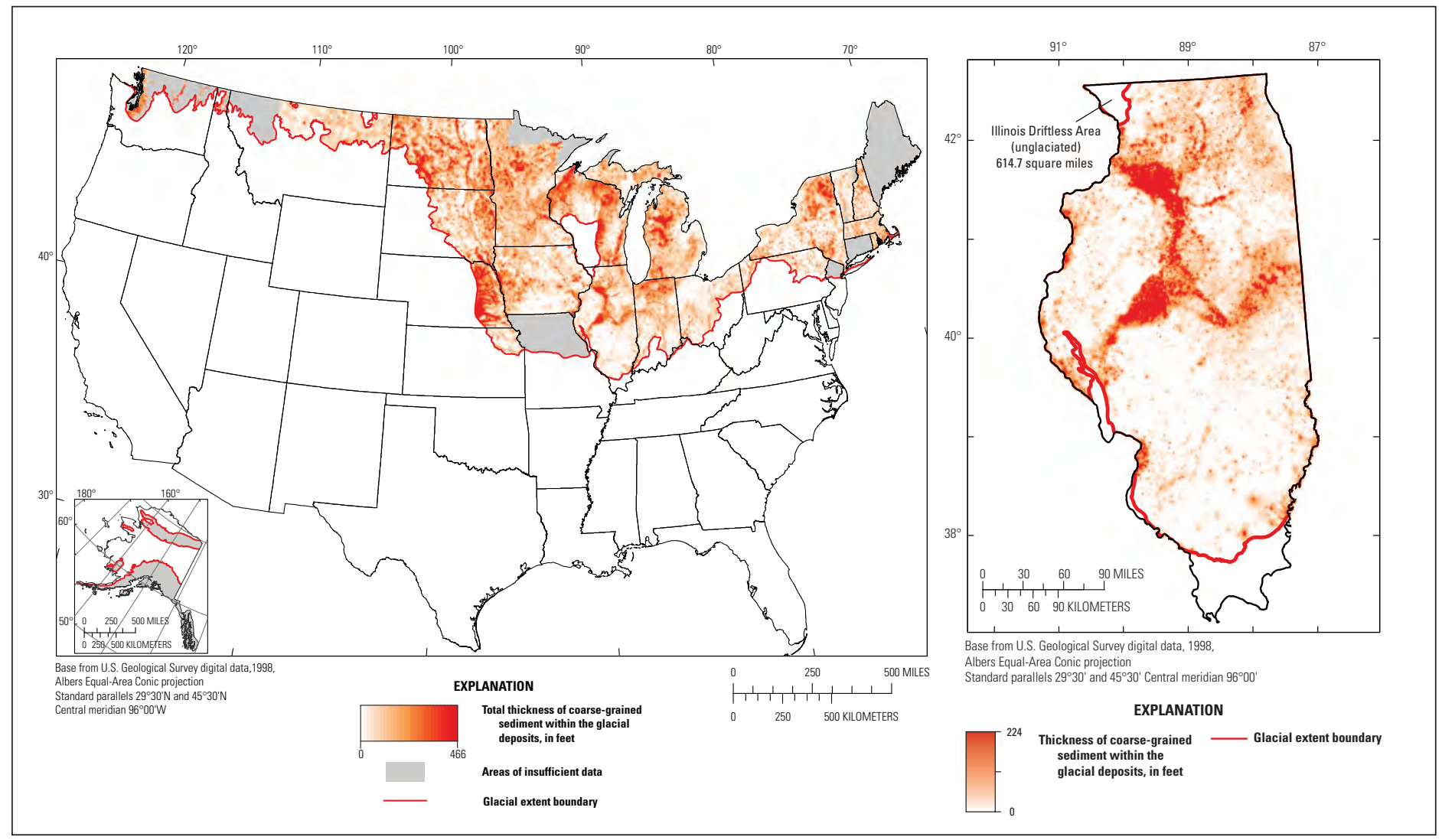

Scientific Investigations Report 2015-5105 
Cover figures. Total thickness of coarse-grained sediment within the glacial deposits of the United States (left), and map created during this study showing the total thickness of coarse-grained sediment within the glacial deposits in Illinois (right). 


\section{Maps and Grids of Hydrogeologic Information Created from Standardized Water-Well Drillers' Records of the Glaciated United States}

By E. Randall Bayless, Leslie D. Arihood, Howard W. Reeves, Benjamin J.S. Sperl, Sharon L. Qi, Valerie E. Stipe, and Aubrey R. Bunch

National Water Availability and Use Program

and the National Water-Quality Assessment Program

Scientific Investigations Report 2015-5105 


\title{
U.S. Department of the Interior SALLY JEWELL, Secretary
}

\section{U.S. Geological Survey Suzette M. Kimball, Director}

\author{
U.S. Geological Survey, Reston, Virginia: 2017
}

For more information on the USGS - the Federal source for science about the Earth, its natural and living resources, natural hazards, and the environment—visit http://www.usgs.gov or call 1-888-ASK-USGS.

For an overview of USGS information products, including maps, imagery, and publications, visit http://store.usgs.gov.

Any use of trade, firm, or product names is for descriptive purposes only and does not imply endorsement by the U.S. Government.

Although this information product, for the most part, is in the public domain, it also may contain copyrighted materials as noted in the text. Permission to reproduce copyrighted items must be secured from the copyright owner.

Suggested citation:

Bayless, E.R., Arihood, L.D., Reeves, H.W., Sperl, B.J.S., Qi, S.L., Stipe, V.E., and Bunch. A.R., 2017,

Maps and grids of hydrogeologic information created from standardized water-well drillers' records of the glaciated United States: U.S. Geological Survey Scientific Investigations Report 2015-5105, 34 p., https://doi.org/10.3133/sir20155105.

ISSN 2328-0328 (online) 


\section{Acknowledgments}

The authors acknowledge the employees of the State agencies that compiled and provided the digital water-well drillers' records that were used as the basis for this study. The authors also acknowledge the following individuals for manually adding additional records: Myles S. Downhour (Indiana University-Purdue University Indianapolis), Jeremy D. Ferguson (Ball State University), Alexandria L. Heald (Ball State University), René M. Lawson (Ball State University), Lewis J. Mason (Indiana University), Dawn R. McCausland (self-employed contractor), Ben A. Weber (Indiana University-Purdue University Indianapolis), and Stacy L. Yager (Ball State University). 



\section{Contents}

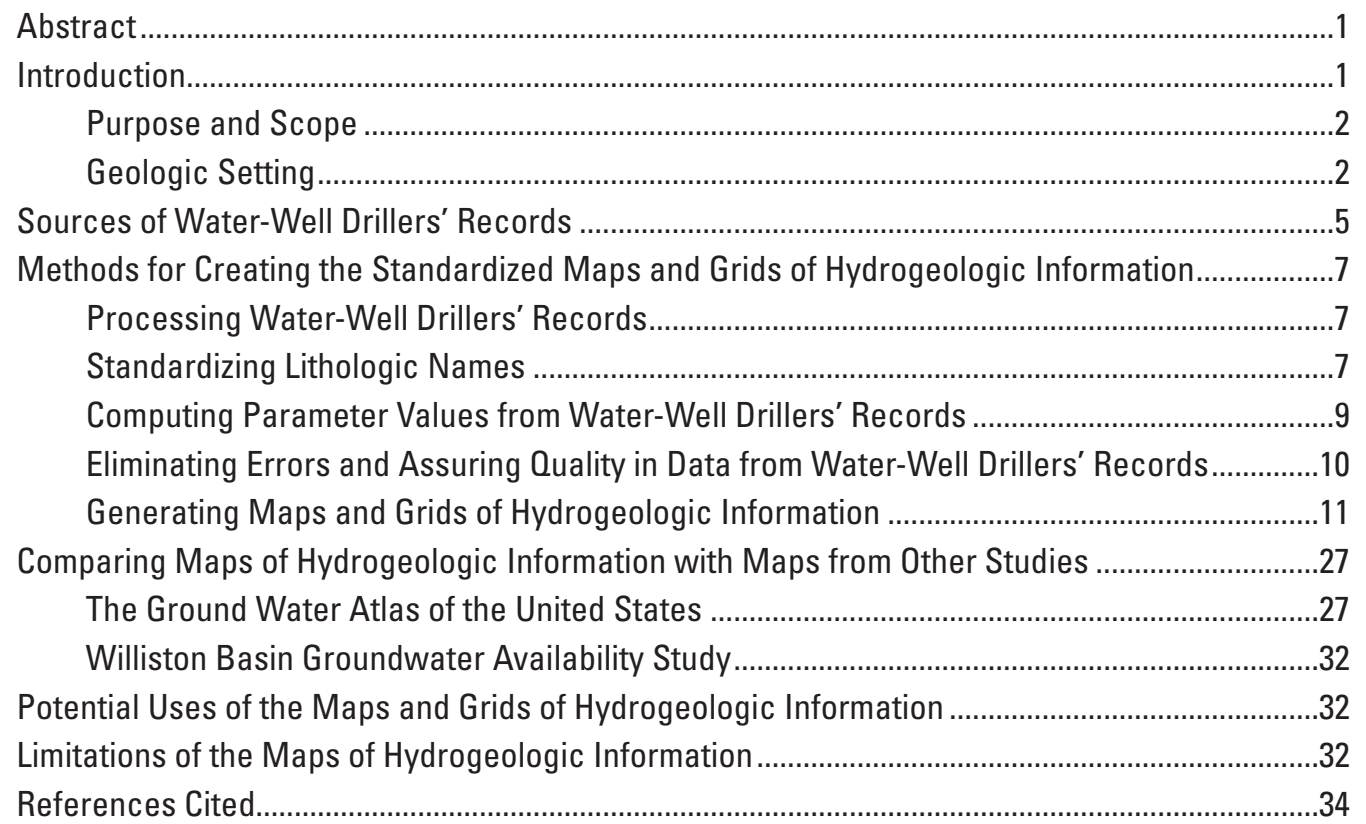

\section{Figures}

1. Map showing areas of the United States overlain by glacial deposits.

2. Map showing areas of North America affected by Cordilleran and Laurentide ice sheets.

3. Flow chart for processing well logs into grids of hydrogeologic information...................8

4. Map showing the spatial density of water-well drillers' records in the glaciated United States

$5 A-B$. Maps showing the hydrogeologic information for Indiana as an example of State maps included in the nationwide mosaics. (Maps of hydrogeologic information for Indiana created from the standardized database of water-well drillers' records, including: $A$, wells completed in bedrock, and $B$, wells completed in glacial deposits).

$5 C-D$. Maps showing the hydrogeologic information for Indiana as an example of State maps included in the nationwide mosaics. (Maps of hydrogeologic information for Indiana created from the standardized database of water-well drillers' records, including: $C$, wells completed in glacial deposits and penetrating at least 50 percent of the total glacial thickness, and $D$, total thickness of glacial deposits)

$5 E-F$. Maps showing the hydrogeologic information for Indiana as an example of State maps included in the nationwide mosaics. (Maps of hydrogeologic information for Indiana created from the standardized database of water-well drillers' records, including: $E$, thickness of coarse-grained sediment within the glacial deposits, and $F$, texture-based estimated equivalent horizontal hydraulic conductivity) 


\section{Figures-Continued}

$5 \mathrm{G}-\mathrm{H}$. Maps showing the hydrogeologic information for Indiana as an example of State maps included in the nationwide mosaics. (Maps of hydrogeologic information for Indiana created from the standardized database of water-well drillers' records, including: $G$, texture-based estimated equivalent vertical hydraulic conductivity, and

$\mathrm{H}$, texture-based estimated equivalent transmissivity of the glacial deposits) .16

$5 \mathrm{I}$-J. Maps showing the hydrogeologic information for Indiana as an example of State maps included in the nationwide mosaics. (Maps of hydrogeologic information for Indiana created from the standardized database of water-well drillers' records, including: $I$, wells completed in bedrock having specific-capacity data, and $J$, wells completed in glacial deposits having specific-capacity data)

$5 K-L$. Maps showing the hydrogeologic information for Indiana as an example of State maps included in the nationwide mosaics. (Maps of hydrogeologic information for Indiana created from the standardized database of water-well drillers' records, including: $K$, wells completed in bedrock and glacial deposits withdrawing more than 100 and 500 gallons per minute, and $L$, specific-capacity based horizontal hydraulic conductivity of coarse-grained sediment within the glacial deposits)

$5 \mathrm{M}$. Maps showing the hydrogeologic information for Indiana as an example of State maps included in the nationwide mosaics. (Maps of hydrogeologic information for Indiana created from the standardized database of water-well drillers' records, including: $M$, specific-capacity based transmissivity of coarse-grained sediment within the glacial deposits)

6. Map showing the thickness of glacial deposits in the United States.

7. Map showing the total thickness of coarse-grained sediment within the glacial deposits of the United States.

8. Map showing the specific-capacity based transmissivity of coarse-grained sediment within the glacial deposits of the United States

9. Map showing the specific-capacity based horizontal hydraulic conductivity of coarse-grained sediment within the glacial deposits of the United States

10. Map showing the texture-based estimated horizontal hydraulic conductivity of the glacial deposits of the United States.

11. Map showing the texture-based estimated vertical hydraulic conductivity of the glacial deposits of the United States.

12. Map showing the texture-based estimated equivalent transmissivity of the glacial deposits of the conterminous United States

13. Map created during this study showing the total thickness of coarse-grained sediment within the glacial deposits in Illinois.

14. Map from the Ground Water Atlas (Miller, 1999, fig. 4, p. K3) showing surficial and buried aquifers in unconsolidated deposits in Illinois

15. Map created during this study showing the thickness of glacial deposits in Illinois .....29

16. Map from the Ground Water Atlas (Miller, 1999, fig. 14, p. K6) showing the thickness of glacial deposits in Illinois...

17. Map created during this study showing the thickness of glacial deposits in lowa........30

18. Map from the Ground Water Atlas (Olcott, 1992, fig. 30, p. J9) showing the thickness of glacial deposits in lowa

19. Map created during this study showing the total thickness of coarse-grained sediment within the glacial deposits in lowa.

20. Map from the Ground Water Atlas (Olcott, 1992, fig. 6, p. J3) showing the distribution of coarse-grained sediment within the glacial deposits in lowa 


\section{Figures-Continued}

21. Map created during this study showing the thickness of glacial deposits in the part of North Dakota modeled by Thamke and others (2014).

22. Map showing the thickness of glacial deposits in North Dakota created by Thamke and others (2014)

\section{Tables}

1. Sources of water-well drillers' records used to evaluate potential sources of information to derive hydrogeologic products .6

2. List of data elements used to create the standardized maps and grids

\section{Conversion Factors}

U.S. customary units to International System of Units

\begin{tabular}{|c|c|c|}
\hline Multiply & By & To obtain \\
\hline \multicolumn{3}{|c|}{ Length } \\
\hline foot $(\mathrm{ft})$ & 0.3048 & meter $(\mathrm{m})$ \\
\hline \multicolumn{3}{|c|}{ Area } \\
\hline square mile $\left(\mathrm{mi}^{2}\right)$ & 259.0 & hectare (ha) \\
\hline square mile $\left(\mathrm{mi}^{2}\right)$ & 2.590 & square kilometer $\left(\mathrm{km}^{2}\right)$ \\
\hline \multicolumn{3}{|c|}{ Flow rate } \\
\hline foot per day (ft/d) & 0.3048 & meter per day $(\mathrm{m} / \mathrm{d})$ \\
\hline gallon per minute (gal/min) & 0.06309 & liter per second $(\mathrm{L} / \mathrm{s})$ \\
\hline million gallons per day (Mgal/d) & 0.04381 & cubic meter per second $\left(\mathrm{m}^{3} / \mathrm{s}\right)$ \\
\hline $\begin{array}{l}\text { million gallons per day per square } \\
\text { mile }\left[(\mathrm{Mgal} / \mathrm{d}) / \mathrm{mi}^{2}\right]\end{array}$ & 1,461 & $\begin{array}{l}\text { cubic meter per day per square } \\
\text { kilometer }\left[\left(\mathrm{m}^{3} / \mathrm{d}\right) / \mathrm{km}^{2}\right]\end{array}$ \\
\hline \multicolumn{3}{|c|}{ Transmissivity* } \\
\hline foot squared per day $\left(\mathrm{ft}^{2} / \mathrm{d}\right)$ & 0.09290 & meter squared per day $\left(\mathrm{m}^{2} / \mathrm{d}\right)$ \\
\hline \multicolumn{3}{|c|}{ Application rate } \\
\hline $\begin{array}{l}\text { pounds per acre per year } \\
{[(\mathrm{lb} / \mathrm{acre}) / \mathrm{yr}]}\end{array}$ & 1.121 & $\begin{array}{l}\text { kilograms per hectare per year } \\
{[(\mathrm{kg} / \mathrm{ha}) / \mathrm{yr}]}\end{array}$ \\
\hline \multicolumn{3}{|c|}{ Leakance } \\
\hline foot per day per foot $[(\mathrm{ft} / \mathrm{d}) / \mathrm{ft}]$ & 1 & meter per day per meter \\
\hline inch per year per foot $[(\mathrm{in} / \mathrm{yr}) / \mathrm{ft}]$ & 83.33 & $\begin{array}{l}\text { millimeter per year per meter } \\
\qquad[(\mathrm{mm} / \mathrm{yr}) / \mathrm{m}]\end{array}$ \\
\hline
\end{tabular}




\section{Datum}

Vertical coordinate information is referenced to the North American Vertical Datum of 1988 (NAVD 88).

Horizontal coordinate information is referenced to the North American Datum of 1983 (NAD 83).

Altitude, as used in this report, refers to distance above the vertical datum.

\section{Supplemental Information}

Transmissivity: The standard unit for transmissivity is cubic foot per day per square foot times foot of aquifer thickness [(ft $\left./ \mathrm{d}) / \mathrm{ft}^{2}\right] \mathrm{ft}$. In this report, the mathematically reduced form, foot squared per day $\left(\mathrm{ft}^{2} / \mathrm{d}\right)$, is used for convenience.

\section{Abbreviations}

AML Arc Macro Language

ASCII American Standard Code for Information Interchange

GWSI Ground Water Site Inventory

INFO The database that supports geographic information system manipulations in ARC/INFO

JPEG Joint Photographic Experts Group

PDF Adobe portable document format

TIFF Tagged Image File Format

USGS U.S. Geological Survey 


\title{
Maps and Grids of Hydrogeologic Information Created from Standardized Water-Well Drillers' Records of the Glaciated United States
}

\author{
By E. Randall Bayless, Leslie D. Arihood', Howard W. Reeves, Benjamin J.S. Sperl, Sharon L. Qi, \\ Valerie E. Stipe ${ }^{2}$, and Aubrey R. Bunch
}

\section{Abstract}

As part of the National Water Availability and Use Program established by the U.S. Geological Survey (USGS) in 2005, this study took advantage of about 14 million records from State-managed collections of water-well drillers' records and created a database of hydrogeologic properties for the glaciated United States. The water-well drillers' records were standardized to be relatively complete and error-free and to provide consistent variables and naming conventions that span all State boundaries.

Maps and geospatial grids were developed for (1) total thickness of glacial deposits, (2) total thickness of coarsegrained deposits, (3) specific-capacity based transmissivity and hydraulic conductivity, and (4) texture-based estimated equivalent horizontal and vertical hydraulic conductivity and transmissivity. The information included in these maps and grids is required for most assessments of groundwater availability, in addition to having applications to studies of groundwater flow and transport. The texture-based estimated equivalent horizontal and vertical hydraulic conductivity and transmissivity were based on an assumed range of hydraulic conductivity values for coarse- and fine-grained deposits and should only be used with complete awareness of the methods used to create them. However, the maps and grids of texturebased estimated equivalent hydraulic conductivity and transmissivity may be useful for application to areas where a range of measured values is available for re-scaling.

Maps of hydrogeologic information for some States are presented as examples in this report but maps and grids for all States are available electronically at the project Web site (USGS Glacial Aquifer System Groundwater Availability Study, http://mi.water.usgs.gov/projects/ WaterSmart/Map-SIR2015-5105.html) and the Science Base Web site, https://www.sciencebase.gov/catalog/ item/58756c7ee4b0a829a3276352 (Bayless and others, 2017).

\section{Introduction}

At the request of Congress, the U.S. Geological Survey (USGS) is assessing the availability and use of the Nation's water resources. In 2005, the USGS established the National Water Availability and Use program (U.S. Geological Survey, 2002), which was designed to characterize the quantity of available surface and groundwater and improve understanding of trends in water use and future availability. This study also addresses the goals of the USGS National Water Census (U.S. Geological Survey, 2007, http://water.usgs.gov/watercensus/, accessed January 2, 2015) and the SECURE Water Act (National Science and Technology Council, 2007, http:// www.usbr.gov/climate/Secure/docs/SECUREWaterReport.pdf, accessed January 2, 2015). Those goals include developing new tools to facilitate assessments of water availability at the regional and national scale. The Great Lakes Basin was chosen as a pilot study area, and methods were developed to standardize water-well drillers' records and create maps and geospatial grids of hydrogeologic information for the glaciated parts of the basin (Arihood, 2009). Those methods were adapted and enhanced for this study.

Water-well drillers' records may be the single largest source of data that are available to describe the geologic deposits of the subsurface. Drillers' records are collected by one or more agencies in each State on a volunteer or mandated basis, and most are available online (Steve Schneider, Schneider Water Services, NGWA Groundwater Forum, written commun., 2014). Water-well drillers' records generally include similar information, including well-location information, depth-specific descriptions of the geologic materials that were penetrated during drilling, the depth to groundwater, the dimensions and types of materials used to construct the well, and well-development data. The digital format of the drillers' records varies among States and includes Microsoft Excel

${ }^{1}$ Scientist Emeritus, U.S. Geological Survey

${ }^{2}$ USGS Volunteer for Science 
spreadsheets, Microsoft Access databases, geodatabases, text files, and scanned images in Joint Photographic Experts Group (JPEG) format or Adobe portable document format (PDF). The spatial density of water-well drillers' records also varies greatly among States depending on the requirements of State laws, the level of driller cooperation, the preferred use of glacial aquifers relative to bedrock aquifers, and the occurrence and extent of glacial aquifers.

Regional hydrologic studies, such as the USGS National Water Availability and Use program investigations (http:// water.usgs.gov/ogw/gwrp/activities/water-avail-use.html, accessed January 4, 2014) and the USGS National WaterQuality Assessment Program (http://water.usgs.gov/nawqa, accessed January 4, 2014), can benefit greatly from regional maps and geospatial grids of hydrogeologic information. Those studies commonly examine areas that include multiple States. Standardized water-well drillers' records include uniform data elements that are similarly populated and use similar terminology and physical units. The availability of nationwide standardized maps of hydrogeologic information facilitate hydrologic studies that cross State boundaries by eliminating (1) differences in the digital and layout formats that are present in various State-managed collections of water-well drillers' records, (2) regional naming conventions for geologic deposits, and (3) errors that appear in water-well drillers' records.

The maps and geospatial grids created as part of this study apply to a variety of hydrogeologic studies. As part of this study, for example, the geospatial grids were used to create maps of hydrogeologic information that describe the thickness and texture of unconsolidated glacial deposits and their related hydrologic characteristics. The distribution of geologic deposits form the framework of most groundwater studies, and it follows that the standardized maps and grids of hydrogeologic properties could be applied to studies of groundwater availability, flow, contaminant transport, aquifer recharge, and groundwater/surface-water interaction. Feinstein and others (2010), for example, used similarly constructed maps of hydrogeologic properties to construct a groundwater-flow model of the Lake Michigan drainage basin and examined the impacts of groundwater withdrawals on aquifer systems and stream discharges.

The methods used to create the geospatial grids and maps of hydrogeologic information were largely developed and documented for use in assessing water availability and use in the Lake Michigan drainage basin (Arihood, 2009). Those methods were augmented for this study with additional steps to further improve the quality of the records and to address the unique situations encountered within the various collections of water-well drillers' records used for this study. This report focuses on the new processing steps and refers the reader to Arihood (2009) for the details of steps that were previously documented.

This report addresses goals of the USGS National Water Census (http://water.usgs.gov/watercensus, accessed January 2, 2015) and the SECURE Water Act (http://www.usbr/gov/ climate/SECURE/docs/SECUREWaterReport.pdf, accessed
January 2, 2015) that pertain to developing new tools to facilitate assessments of water availability at the regional and national scale. This research also provides information that improves the decision-support capacity for water-resource managers. Information provided by the geospatial grids of hydrogeologic information can further facilitate the estimation of water availability in the Nation's glacial aquifer systems.

\section{Purpose and Scope}

The purpose of this report is to describe (1) the contents of the standardized water-well drillers' records and the derivative hydrogeologic products, (2) newly implemented methods used to standardize water-well drillers' records for glaciated parts of the United States, (3) sources of water-well drillers' records used in this study, (4) quality-assurance steps used to eliminate records with inconsistent or insufficient information, (5) new maps of hydrogeologic information, and (6) comparisons of maps created by this study with similar maps created by other studies. This report describes methods for creating geospatial grids and maps from water-well drillers' records for U.S. territory that is overlain by glacial deposits (fig. 1), which includes all or part of 25 States and extends from the Atlantic Ocean to the Pacific Ocean and from Alaska to the Ohio River. About 14 million water-well drillers' records from State-managed collections were used for this study.

\section{Geologic Setting}

The glacial advances and retreats of the Pleistocene epoch (2,000,000 to 10,000 years BC; http://igs.indiana.edu/ Surficial/IceAge.cfm, accessed January 20, 2015) left vast deposits of various geologic materials over much of North America. The deposits west of the Rocky Mountain continental divide were deposited by the Cordilleran ice sheet, and the deposits east of the divide were deposited by the Laurentide ice sheet (fig. 2). The southern extent of glacial deposits generally includes areas north of the Missouri and Ohio Rivers.

States included in this study and influenced by the Cordilleran ice sheet include Idaho, Washington, Alaska, and western Montana. The Laurentide ice sheet created the glacial deposits in the remaining 21 States included in this study.

In this study, water-well drillers' records indicated that glacial deposits range from 0 to about 1,200 feet (ft) thick. Glacial deposits were absent in some areas of prominent bedrock highlands such as central Wisconsin and mountainous areas of the Rocky Mountains (fig. 1). The textures of glacial deposits range from very fine (clay-rich) lacustrine deposits to relatively coarse (sand and (or) gravel-rich) kames, eskers, outwash, and alluvial deposits. The variability of textures range from relatively homogeneous deposits of eolian sands with consistent texture through great thicknesses to glacial till deposits with heterogeneous mixtures of coarse- and finetextured materials. 


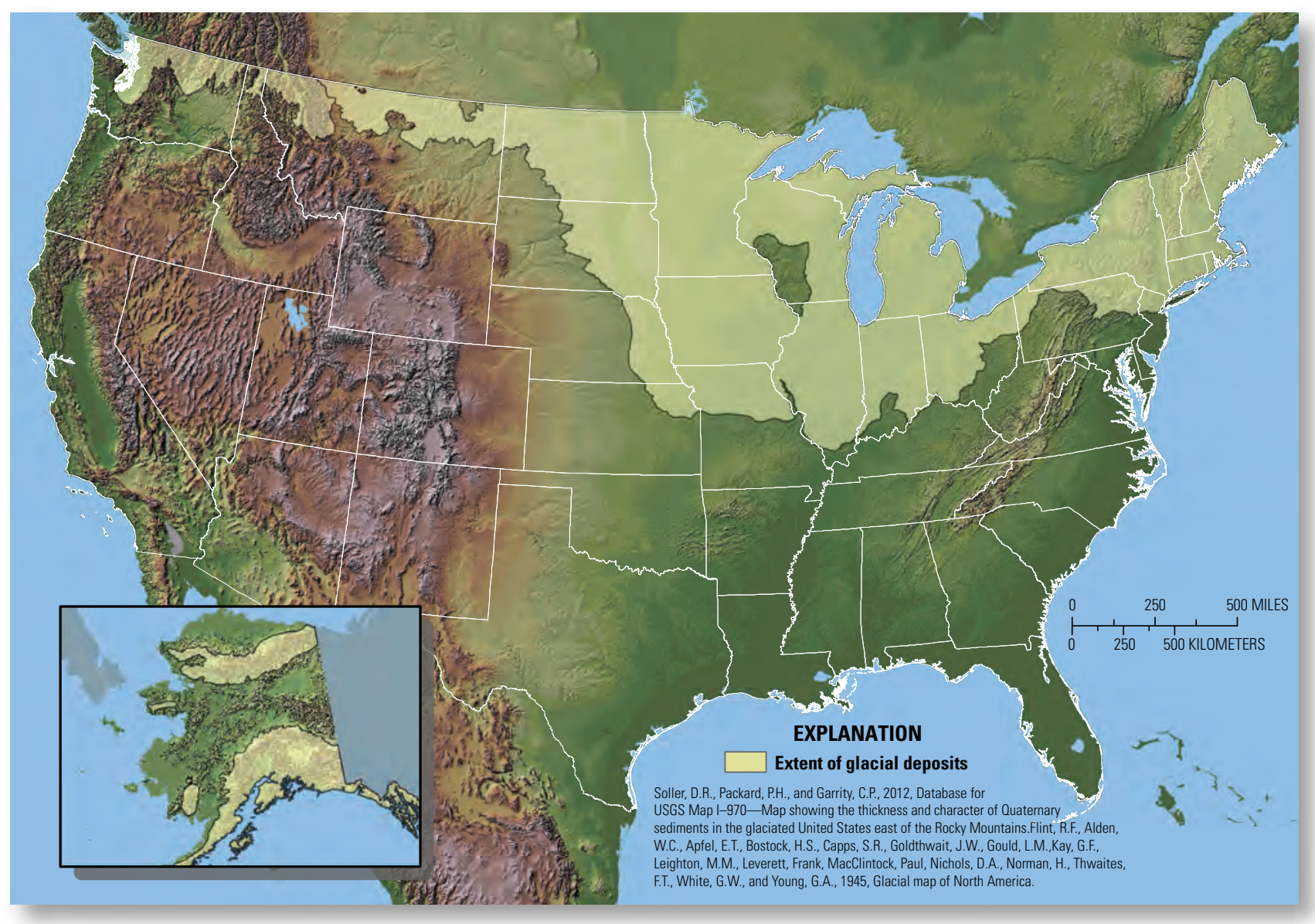

Figure 1. Areas of the United States overlain by glacial deposits. 


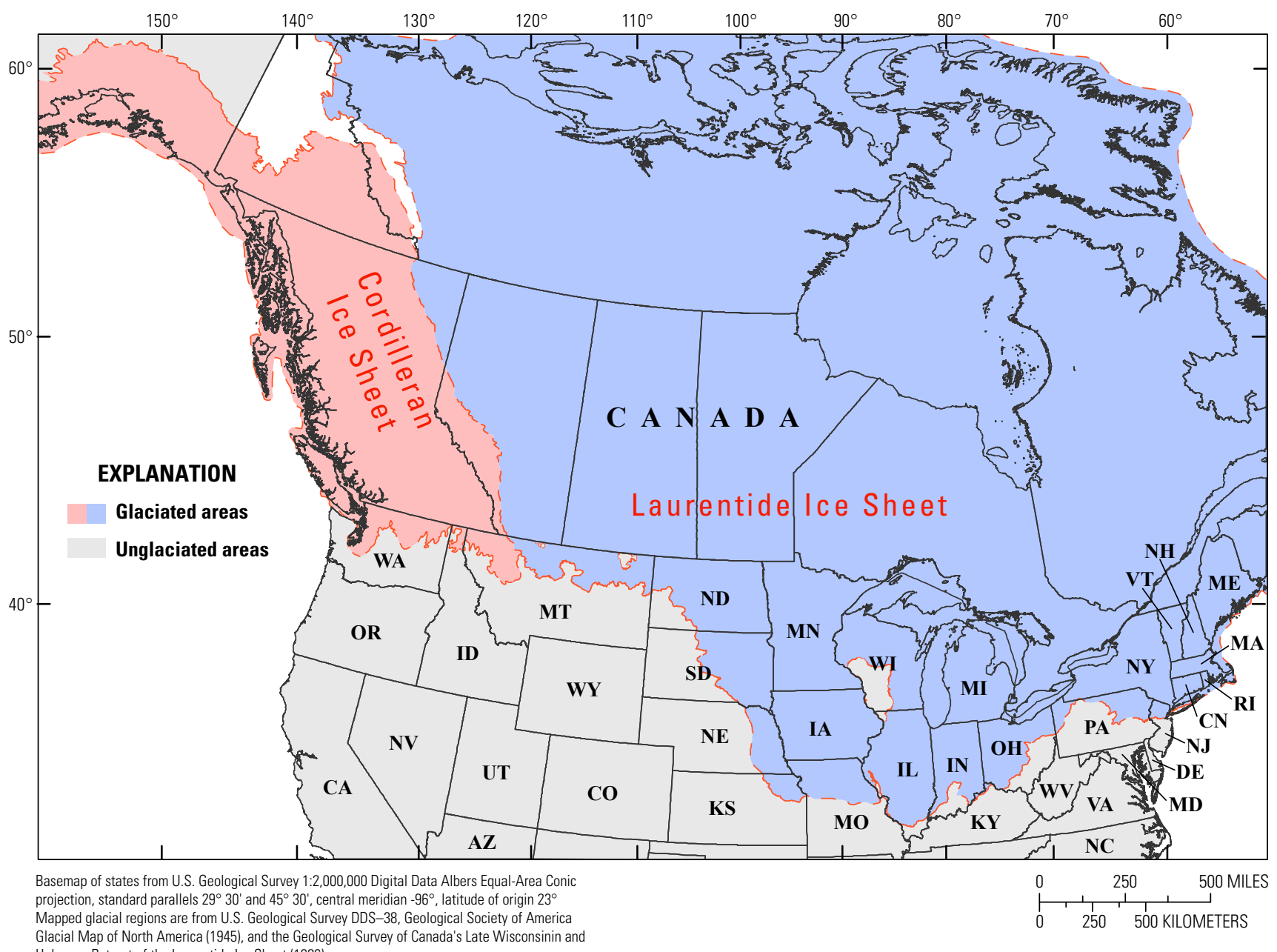

( Geological Survey of Canada's Late Wisconsinin and

Figure 2. Areas of North America affected by Cordilleran and Laurentide ice sheets. 
The unlithified character of glacial deposits provides them with porosities that generally exceed the porosities of bedrock formations and creates in them the capacity to hold large quantities of groundwater (Warner and Arnold, 2006). Warner and Arnold (2006) reported that glacial aquifers comprise the largest principal aquifer system in the United States in areal extent and groundwater use for public supply in the United States. The areal extent, near-surface accessibility, and water-holding capacity explain the widespread utilization of glacial aquifers for domestic, agricultural, commercial, and industrial water supplies throughout much of the United States. During 2000, the total withdrawals of groundwater from the glacial aquifer system were approximately 3,560 million gallons per day $(\mathrm{Mgal} / \mathrm{d})$ and represented about 5 percent of total withdrawals from all aquifers in the United States (Maupin and Barber, 2005). Glacial sand-and-gravel aquifers east of the Rocky Mountains are largely used for public supply (1,950 Mgal/d), irrigation (1,020 Mgal/d), and self-supplied industrial (583 Mgal/d) uses (Maupin and Barber, 2005).

The vertical and lateral distribution of coarse- and finegrained deposits affects many aquifer characteristics, including the rate of aquifer replenishment (recharge), the interaction between groundwater and surface-water, the general chemistry of groundwater, and the movement of natural and anthropogenic compounds through the subsurface. These characteristics determine the potability and availability of groundwater for various uses. Inter-till aquifers, for example, may be overlain with significant thicknesses of fine-grained deposits near land surface. For this reason, inter-till aquifers may be slow to replenish and have limited water availability but also be well protected from chemicals applied at land surface. Outwash aquifers may include thick and extensive surficial deposits of sand and gravel. Those aquifers may be quicker to replenish and have greater availability than till aquifers but are more vulnerable to contamination from the chemicals applied at land surface.

Most U.S. States have maps that depict the surficial distribution of unlithified deposits, and many identify the morphological nature of the associated landforms. Those maps are largely two dimensional in perspective and do not portray variability with depth. Maps that display the three-dimensional geology of glacial deposits are less common; however, Soller and Reheis (2004) produced a large-scale map that shows the lateral and vertical distribution of coarse- and fine-grained deposits for glaciated terrains east of the Rocky Mountains. That map was later refined (Soller and others, 2012) and made available as geospatial grids. Other examples of glacial maps that provide three-dimensional information include, for example, Berg and Kempton (1988). This report contains maps and grids that provide extensive and detailed hydrogeologic information relative to the third dimension (depth), or that which lies beneath the surface features.

\section{Sources of Water-Well Drillers' Records}

Water-well drillers' records were acquired from the State agencies that are responsible for compiling and managing those records (table 1). Oil and gas well records, and records for drilling activities focused on mineral deposits in the bedrock, were another potential source of information for this study but those logs also do not normally contain detailed descriptions of the glacial deposits and hydraulic testing that were the focus of this study. As a result, only water-well drillers' records were used for this study.

The collections of water-well drillers' records that are managed by States vary in size, spatial density, completeness, digital format, and legal requirements. The number of digital water-well drillers' records in State-managed collections for this study ranged from zero to more than 1 million. This number of records does not include those drillers' records that might be available in paper form or as scanned forms. Only 15 States had digital collections of water-well drillers' records that included well-record information in a format that could be easily manipulated. The 10 remaining States had part or none of their collection of water-well drillers' records in a digital form that was manipulatable by the programs used in this study. Rhode Island, for example, has collected thousands of paper records from water-well drillers that are not available in digital format. Other States, such as Washington and South Dakota, have well-construction information available in a manipulatable digital format but lithologic information was available only as scanned images of the original water-well drillers' records.

The data elements sought by this study are unique site identifier, geographic location, well depth, water level, landsurface altitude, well screen depth and length, casing length and diameter, construction date, well development data (pump rate, pump duration, and drawdown), water use, owner, and the lithologies encountered at various depths during well installation. The data elements contained in State-managed collections of water-well drillers' records were not always consistent. In general, data elements in most State collections included location, owner, intended water use, well construction, well development, and lithology. The data elements most commonly lacking in State collections of water-well drillers' records were complete well-construction and well-development information. For the purposes of this study, missing wellconstruction and well-development data precluded the ability to compute aquifer transmissivity and hydraulic conductivity values. Water-well drillers' records were not used to create maps and geospatial grids of hydrogeologic information if critical well-location and lithology data were missing. 
Table 1. Sources of water-well drillers' records used to evaluate potential sources of information to derive hydrogeologic products.

[shapefile, geospatial vector data for use with a geographic information system; PDF, Adobe portable document format; TIFF, tagged image file format; database, electronic database]

\begin{tabular}{|c|c|c|c|}
\hline State $^{1}$ & Responsible agency & $\begin{array}{l}\text { Original well } \\
\text { construction } \\
\text { file format }\end{array}$ & $\begin{array}{l}\text { Original lithology } \\
\text { file format }\end{array}$ \\
\hline Alaska & Alaska Department of Natural Resources & shapefile & PDF \\
\hline Connecticut & Connecticut Department of Consumer Protection & TIFF & TIFF \\
\hline Idaho & Idaho Department of Water Resources & shapefile & PDF \\
\hline Illinois & Illinois State Geological Survey & database & database \\
\hline Iowa & Iowa Department of Natural Resources & database & database \\
\hline Iowa (2) & University of Iowa & database & PDF \\
\hline Kansas & Kansas Geological Survey & database & PDF \\
\hline Massachusetts & Massachusetts Department of Environmental Protection & database & database \\
\hline Missouri & Missouri Department of Natural Resources & database & database \\
\hline Montana & Montana Bureau of Mines and Geology & database & database \\
\hline Nebraska incomplete & Nebraska Department of Natural Resources & database & database \\
\hline Nebraska (2) & University of Nebraska & database & database \\
\hline New Hampshire incomplete & New Hampshire Department of Environmental Services & $\begin{array}{l}\text { database } \\
\text { and PDF }\end{array}$ & $\begin{array}{l}\text { database } \\
\text { and PDF }\end{array}$ \\
\hline New Jersey & New Jersey Department of Environmental Protection & database & database \\
\hline New York incomplete & New York State Department of Environmental Conservation & PDF & PDF \\
\hline North Dakota & North Dakota State Water Commission & database & database \\
\hline Washington incomplete & Washington State Department of Ecology & database & PDF \\
\hline Wisconsin & Wisconsin Geological and Natural History Survey & database & database \\
\hline Wisconsin (2) & Wisconsin Department of Natural Resources & database & database \\
\hline
\end{tabular}

${ }^{1}$ States with multiple agencies maintaining well-record databases are designated with a "(2)". 
The water-well drillers' records for some States did not include detailed descriptions of the glacial deposits. In those States, the primary source of potable water was usually bedrock aquifers or surface water and the unconsolidated deposits are commonly described as "overburden." The glacial deposits in those areas may be thin or contain little coarse-grained, water-bearing material so that they are not useful aquifers. Those records were included in the analysis but may not provide the most reliable description of the lithology of the glacial deposits.

\section{Methods for Creating the Standardized Maps and Grids of Hydrogeologic Information}

The methods used in this study were largely documented in Arihood (2009). In that study, Arihood (2009) created maps and geospatial grids of hydrogeologic information for the glacial deposits in Michigan and parts of Indiana and Wisconsin. In this study, those methods have been augmented to adapt to the varied information encountered in water-well drillers' records from all 25 glaciated States. Programming also was added to improve the efficiency of the well-record processing, create grids and maps of additional information, and provide easy construction of geological sections.

\section{Processing Water-Well Drillers' Records}

Water-well drillers' records were digitized by the USGS for States without records in a manipulatable format. Drillers' records were manually entered into a spreadsheet for processing by the programs used in this study. The minimum number of well records needed to create reliable maps was estimated by examining the density of drillers' records in States with existing digital collections that successfully produced sufficiently detailed maps of hydrologic information. For States with paper forms or PDF well records, wells were selected for entry using the following criteria: (1) geographic distribution across the glaciated region of that State, (2) other information that included well depth and (or) percentage of glacial deposits that were penetrated, and (3) availability of detailed lithologic description of the glacial deposits penetrated during well installation. The density of water-well drillers' records could not be equally distributed in States with a predominance of valley-fill aquifers.
A system of Arc Macro Language (AML) programs was used to standardize water-well drillers' records and create maps and geospatial grids of hydrogeologic information for the glaciated States (fig. 2). The data processing, algorithms, and underlying equations used to convert (1) water-well drillers' descriptions into standard lithologic names used in the USGS Groundwater Site Inventory (GWSI), (2) standardized lithology descriptions into texture-based values of estimated equivalent horizontal and vertical hydraulic conductivity, and (3) well-development data into values of actual transmissivity and horizontal hydraulic conductivity are presented in Arihood (2009) and are not described in this report. Only new and (or) improved processing steps and related data manipulations are described herein. A general description of the work flow followed during well-record processing is shown in figure 3.

The agency responsible for managing water-well drillers' records was contacted in each State and asked to provide their water-well drillers' records in two data files identified as the site file and the lithology file (table 2). Additional information requested from the States was needed to describe the geographic projection and datum. Most States also provided a text file describing the information contained in each of the data fields.

Data were provided to the USGS by the States in a variety of formats including Microsoft Excel spreadsheets; Microsoft Access databases; geodatabases; text files; and scanned images in JPEG, PDF, or TIFF format. Data were converted to tab-delimited text files that could be read by the AML programs. Data that were not necessary to processing steps, such as casing material, or information that might be considered to be personally identifiable information, such as street addresses, were deleted from the files.

\section{Standardizing Lithologic Names}

As described in Arihood (2009), the file of water-well drillers' descriptions of lithologies that were encountered at various depth intervals was converted to an INFO file. The water-well drillers' descriptions were then converted by an AML into geologic textural terms that are listed in the USGS GWSI lithology codes (Mathey, 1989, p. 2-110) and given an "aquifer" or "non-aquifer" material designation. The interpreted lithologies were spot-checked to assure that accurate translations of the drillers' terms were made by the AML. Approximately 500 verification checks were made on each file of lithologies.

Lithologic terms were encountered during processing of water-well drillers' records for the 25-State study area that had not been encountered during the Lake Michigan pilot study. About 1,000 lithologic descriptors were required to translate the water-well drillers' descriptions into GWSI lithology codes. 


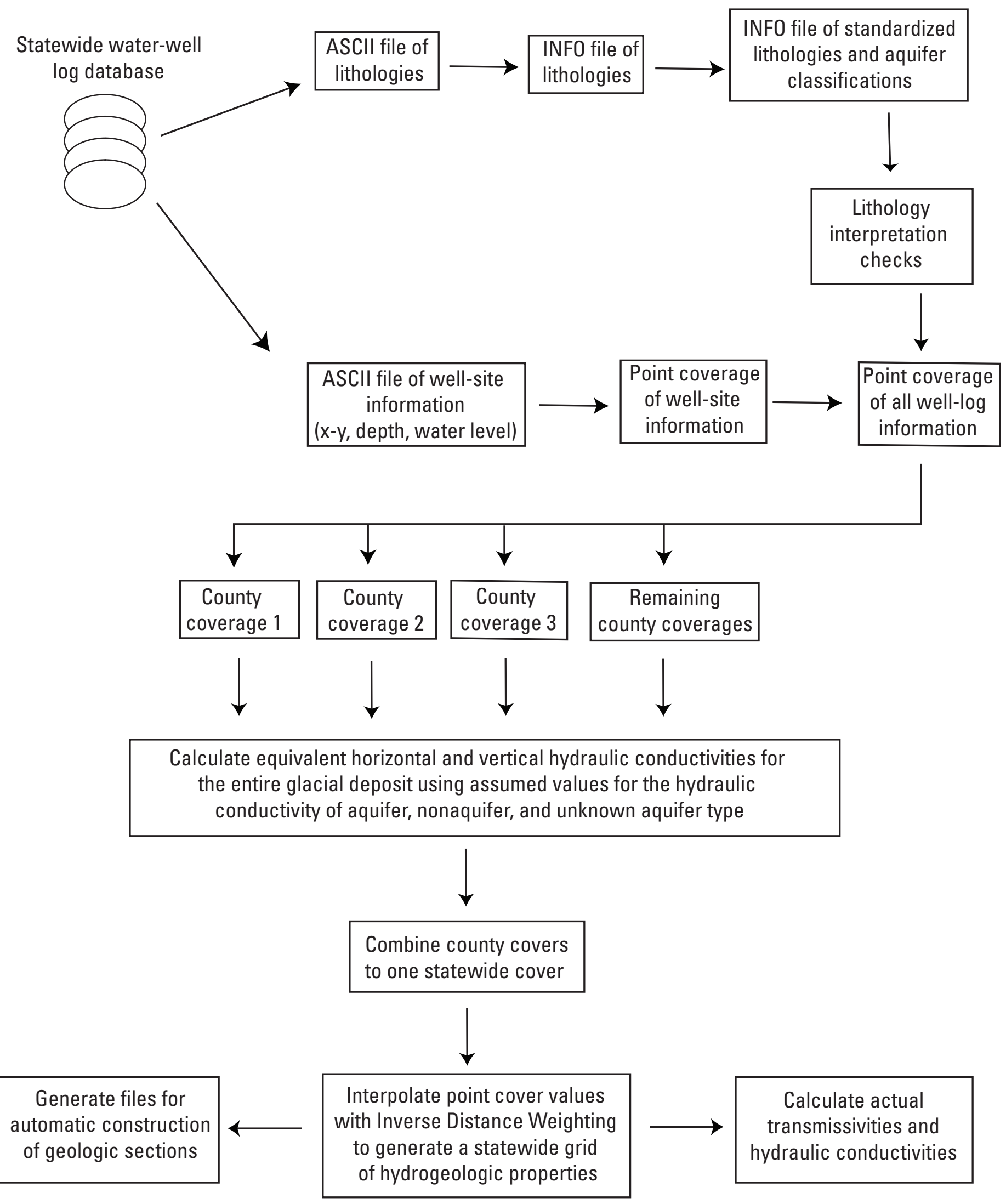

Figure 3. Flow chart for processing well logs into grids of hydrogeologic information. 
Table 2. List of data elements used to create the standardized maps and grids.

\begin{tabular}{|c|c|}
\hline \multicolumn{2}{|r|}{ Site file } \\
\hline Data element & Description of data element \\
\hline Unique site identifier & The unique identifier assigned to each site by the State. \\
\hline Horizontal coordinates & Horizontal location information such as latitude and longitude. \\
\hline Depth to water & The depth to static water level below the measuring point. \\
\hline Measuring-point elevation & The elevation of the measuring point for the depth to water measurement. \\
\hline Land-surface elevation & The land-surface elevation at the well site. \\
\hline Screen length & The length of the well screen. \\
\hline Casing length & The length of the well casing. \\
\hline Casing diameter & The inner diameter of the casing. \\
\hline Construction date & The calendar date of the well construction. \\
\hline Well-development rate & The discharge rate of the pump during well development. \\
\hline Well-development duration & The duration of pumping during well development. \\
\hline Well-development drawdown & The decrease in potentiometric surface elevation during well development. \\
\hline \multicolumn{2}{|r|}{ Lithology File } \\
\hline Data element ${ }^{1}$ & Description of data element \\
\hline Unique site identifier & The unique identifier assigned to each site by the State. \\
\hline Top of formation & The depth below land surface to the top of the geologic formation. \\
\hline Bottom of formation & The depth below land surface to the bottom of the geologic formation. \\
\hline Lithology & $\begin{array}{l}\text { The geologic description provided by the driller for the geologic deposits that exist } \\
\text { between the top of formation and the bottom of formation. }\end{array}$ \\
\hline
\end{tabular}

${ }^{1}$ Data elements in the lithology file are repeated for each lithology described during drilling.

\section{Computing Parameter Values from Water-Well Drillers' Records}

For each State, the INFO lithology file was joined to the well-site information point coverage and an AML program was used to calculate the texture-based estimated equivalent horizontal and vertical hydraulic conductivity, as in the previous study (Arihood, 2009). Specific-capacity based transmissivity and hydraulic conductivity values were computed for wells that included well-development information on the well record (Arihood, 2009). In this study, three new parameters were calculated: (1) total thickness of glacial deposits, (2) thickness of coarse-grained sediment within the glacial deposits, and (3) texture-based estimated equivalent transmissivity of the glacial deposits.

The thickness over which the texture-based estimated equivalent transmissivity, horizontal hydraulic conductivity, and vertical hydraulic conductivity were applied depended on the availability of static water levels in the well-drillers' records. The texture-based estimated equivalent hydraulic properties were computed for the saturated part of the glacial deposits from the static water-level elevation to the bedrocksurface elevation if a majority of the drillers' records in the dataset contained static water levels. These values are more useful to most practicing hydrogeologists because they are pertinent to the portion of glacial deposits containing moving groundwater. The maps depicting texture-based estimated equivalent hydraulic conductivity and transmissivity indicate the upper altitude for the calculation (land surface or potentiometric surface).

The texture-based estimated equivalent hydraulic properties were computed for the entire thickness of glacial deposits-from land-surface elevation to bedrock-surface elevation - if static water levels were not contained in the water-well drillers' records. Static water-level depths were estimated for water-well records without such data in Stateprovided datasets where a majority of records did contain a reported static water level. This was done by fitting a polynomial least-squares regression relation to a plot of land-surface elevation with water-level elevation, and applying the derived relation to water-well records containing land-surface elevation (all wells) but no static water level. Only wells completed in the glacial deposits were used to compute this relation because wells completed in bedrock could portray confinedaquifer conditions and not indicate the water-table condition. 
It is recognized that this decision introduces some nonuniformity into the standardized maps and geospatial grids but it maximizes the value of the texture-based estimated equivalent hydraulic properties for States that record static water levels. The proximity of the static water level to land surface in most glaciated States, relative to the total thickness of glacial deposits, likely reduces the significance of this non-uniformity in the standardized products.

The texture-based values of equivalent transmissivity, horizontal hydraulic conductivity, and vertical hydraulic conductivity were computed based on a percentage of aquifer and non-aquifer material in the glacial deposits by assuming a horizontal hydraulic conductivity of 100 feet per day (ft/d) for aquifer material and $1 \mathrm{ft} / \mathrm{d}$ for non-aquifer material, and a vertical hydraulic conductivity of $10 \mathrm{ft} / \mathrm{d}$ for aquifer material and $0.001 \mathrm{ft} / \mathrm{d}$ for non-aquifer material. These values were selected because they were believed to represent the majority of values for glacial deposits and they would be easily scalable to future applications in hydrologic investigations. The point values of these parameters (texture-based equivalent estimated equivalent transmissivity, horizontal hydraulic conductivity, and vertical hydraulic conductivity) were extrapolated across the entire State by application of an inverse-distance weighting algorithm available within ArcInfo. Details of these methods are described in Arihood (2009).

For this study, however, it was determined that some States would not have the density of drillers' records necessary to extrapolate a reliable map for the entire State. An AML was written to compute spatial density of drillers' records according to the following equation:

$$
D=n / A
$$

where
$D \quad$ is the density of drillers' records, in sites per square mile,
$n \quad$ is the number of sites in the glaciated part of the State penetrating at least 50 percent of the total thickness of glacial deposits, $A$ is the glaciated area of the State, in square miles.

The number and density of drillers' records varied notably among States (fig. 4). Differences in the spatial density of drillers' records may relate to the use of groundwater as a resource and (or) be related to the State's emphasis on populating and maintaining a collection of water-well drillers' records. Maps of hydrogeologic information were created for States with sufficient density of drillers' records. A minimum density value of 0.2 wells per square mile (wells $/ \mathrm{mi}^{2}$ ) was determined to be sufficient to create reliable maps of hydrogeologic information. This value was assessed by comparing the maps generated by this study with maps of hydrogeologic information published by others. For States like Iowa, where drillers' records appeared visually to be spatially well distributed across the glaciated part of the State, a well-record density of 0.2 wells $/ \mathrm{mi}^{2}$ appeared visually to honor the distribution of glacial deposits shown in the Ground Water Atlas of the United States ("the Atlas"; Miller, 1999).

\section{Eliminating Errors and Assuring Quality in Data from Water-Well Drillers' Records}

Many steps in the well-record processing were focused on eliminating well-log data that did not meet the standards established for this project, and those steps included frequently reviewing the results of the data manipulations to assure the quality of the finished product. Application of these steps reduced the available number of drillers' records for each State. In some cases, the number of drillers' records was reduced to the extent that it was not possible to construct maps of hydrogeologic information.

The following list describes the steps taken to eliminate errors and assure quality in the standardized water-well drillers' records. Many of these steps were used in Arihood's (2009) pilot study but were not documented. Some steps have been refined, and other steps have been added for this study including the following:

- Drillers' records were eliminated that did not include the minimum set of required data, such as well-site location information.

- Drillers' records with locations outside of the glaciated part of the State were eliminated.

- Thickness grids with negative values of total glacial thickness, calculated by subtracting bedrock elevation from land-surface elevation, were set to $1 \mathrm{ft}$. These instances may have occurred for various reasons including inaccuracies in the elevation data provided for the site. In this study, it was assumed that all sites have at least a $1 \mathrm{ft}$ thickness of glacial deposits. If there were many locations with negative values of total thickness, or if the negative values were large, they were investigated. In some cases, a new land-surface or bedrock grid was acquired.

- Land-surface elevations from the water-well drillers' records were compared with published maximum and minimum elevations for each State. Land-surface altitudes with elevations more than $20 \mathrm{ft}$ beyond those extremes were deleted from the collection of records.

- Drillers' records for a site where the upper elevation of a formation was higher than the base of the overlying formation resulted in deletion of all records for that site from the dataset. Also, all records for a site were deleted if any value for depth to the top of a formation was greater than the depth to the bottom of that formation. 
- All records of lithology for a well site were deleted if the AML program interpreted a lithologic record to be a glacial deposit located below bedrock.

- The lithologies interpreted by the AML were spotchecked against the original driller's description to help ensure accurate and consistent interpretations.

- If the well log showed that the bedrock surface indicated on the water-well drillers' record was lower than the Soller and others (2012) bedrock surface, then the well record was used and the depth to bedrock was modified to match the information in the drillers' record.

- Maps of the thickness of coarse-grained deposits and the total thickness of glacial deposits were compared with published maps of the same, discrepancies were investigated, and errors were eliminated.

- Each grid of hydrogeologic information was displayed and visually inspected for anomalous values. Anomalous data points were visually identified and corrected or eliminated.

- Any value of hydraulic conductivity calculated from specific-capacity data greater than $1,000 \mathrm{ft} / \mathrm{d}$ were assigned $1,000 \mathrm{ft} / \mathrm{d}$.

- The State's spatial density of water-well drillers' records was evaluated for the adequacy to create reasonable maps of hydrogeological information.

- As a quality-assurance check, the total glacial-thickness values were examined. Well sites with glacialthickness values were deleted if they were clearly dissimilar to other nearby values.

\section{Generating Maps and Grids of Hydrogeologic Information}

The number and content of maps of hydrogeologic information generated for each State varied according to the density of water-well drillers' records and the number of data elements contained in the State's records. Only the waterwell drillers' records that penetrated at least 50 percent of the total glacial thickness were used to construct the grids and maps of total thickness of glacial deposits; total thickness of coarse-grained deposits; and texture-based estimated equivalent transmissivity, horizontal hydraulic conductivity, and vertical hydraulic conductivity. The total glacial thickness at well sites was computed by (1) subtracting the value of the bedrock-surface elevation grid (Soller and others, 2012) from the land-surface elevation grid (http://agdc.usgs.gov/data/ usgs/erosafo/300m/300m.html, accessed February 20, 2015) if the well was completed above bedrock, or (2) subtracting the bedrock-surface elevation indicated in the water-well driller's record from the land-surface elevation grid if the well was completed above or below the bedrock-surface elevation.

The following maps were created for States with drillers' record densities exceeding $0.2 \mathrm{wells} / \mathrm{mi}^{2}$.

- Wells completed in bedrock.

-Wells completed in glacial deposits.

- Wells completed in glacial deposits and penetrating at least 50 percent of the total thickness of glacial deposits.

- Total thickness of glacial deposits in the United States.

- Thickness of coarse-grained sediment within the glacial deposits of the United States.

- Texture-based estimated equivalent horizontal hydraulic conductivity of the glacial deposits in the United States.

- Texture-based estimated equivalent vertical hydraulic conductivity of the glacial deposits in the United States.

- Texture-based estimated equivalent transmissivity of the glacial deposits in the United States.

The following additional maps were created for States with water-well drillers' records that included well-development data.

- Wells completed in bedrock and having specific-capacity data.

- Wells completed in glacial deposits and having specificcapacity data.

- Wells completed in bedrock and glacial deposits withdrawing more than 100 and $500 \mathrm{gal} / \mathrm{min}$, respectively.

- Specific capacity based horizontal hydraulic conductivity of coarse-grained sediment within the glacial deposits of the United States.

- Specific-capacity based transmissivity of coarse-grained sediment within the glacial deposits of the United States.

The density of water-well drillers' records was satisfactory to create some maps and grids for most States (fig. 4). Water-well drillers' records were lacking in density or detailed description of the unconsolidated geology in Alaska, Connecticut, Maine, Missouri, and New Jersey; glaciated parts of those states are identified in the maps of hydrogeologic information as areas of insufficient data. Parts of Idaho, Michigan, Minnesota, Montana, Vermont, Washington, and Wisconsin also contained areas of insufficient data. In those States, the water-well drillers' record density was less than 0.2 wells $/ \mathrm{mi}^{2}$ because the areas are sparsely populated or the hydrogeology is characterized by valley-fill aquifers. In States with valley-fill aquifers (where wells are concentrated in small areas), maps of 


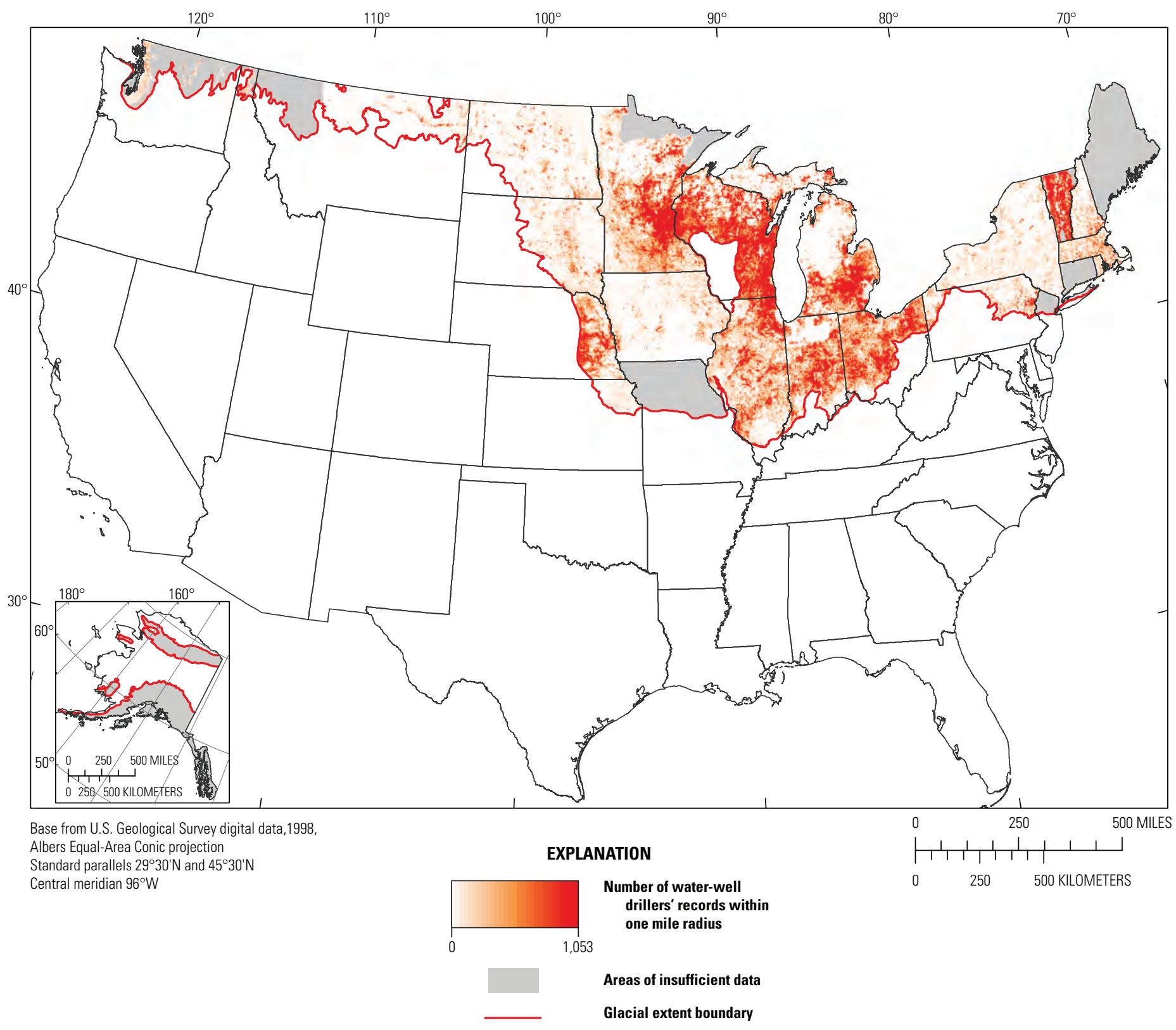

Figure 4. Spatial density of water-well drillers' records in the glaciated United States.

hydrogeologic information were only compiled for the valleyfill aquifers. Areas separating the valleys were not mapped because the inverse-distance weighting process could not generate reliable results.

Twelve States had the data required to create eight maps and grids and eight States had the data required to create 13 maps and grids. The State of Indiana had a processed wellrecord density of $2.70 \mathrm{well} / \mathrm{mi}^{2}$ and contained all of the data elements required to create a full suite of maps. The maps of hydrogeologic information created for the State of Indiana are provided as an example in figure 5 .

The maps and grids of hydrogeologic properties for the individual States were combined into nationwide grids to show regional trends and facilitate large-scale studies that cross State boundaries (figs. 6-12). The figures show where the hydrogeologic properties are mapped and areas with insufficient data. 
$\boldsymbol{A}$

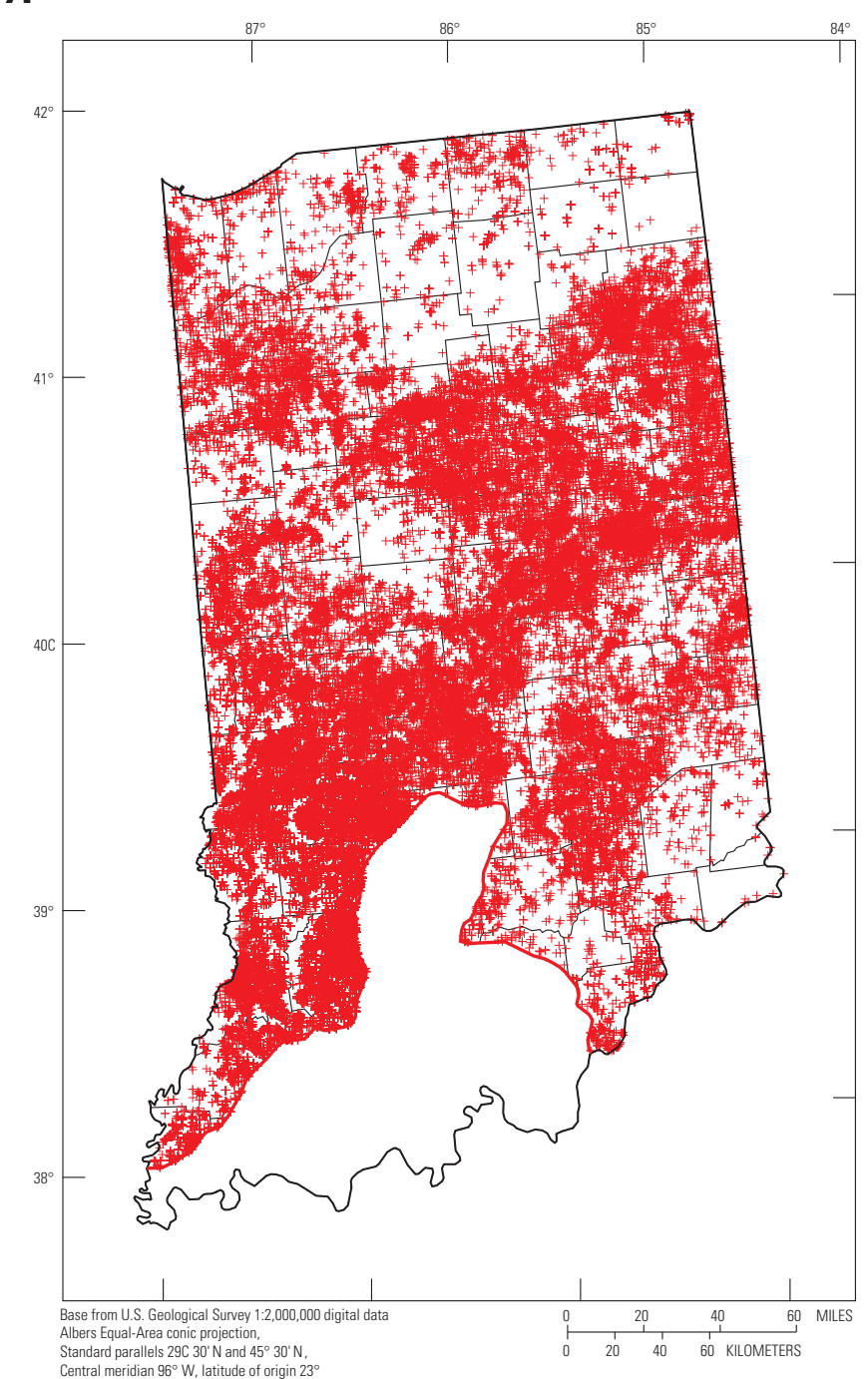

B

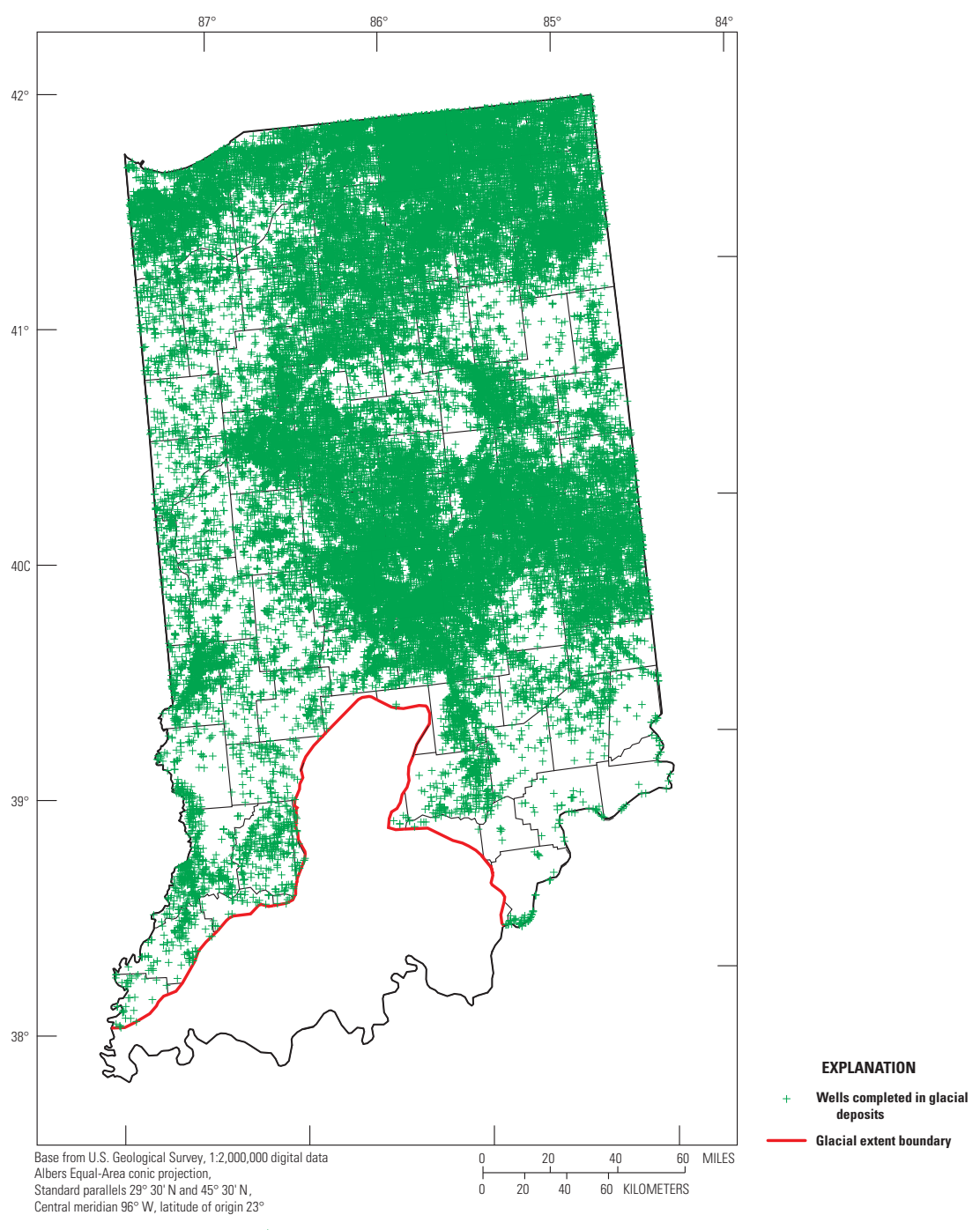

Figure $\mathbf{5} \boldsymbol{A}-\boldsymbol{B}$. Hydrogeologic information for Indiana as an example of State maps included in the nationwide mosaics. (Maps of hydrogeologic information for Indiana created from the standardized database of water-well drillers' records, including: $A$, wells completed in bedrock, and $B$, wells completed in glacial deposits.)

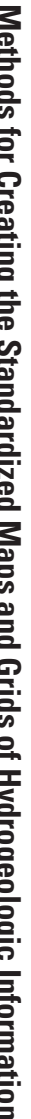

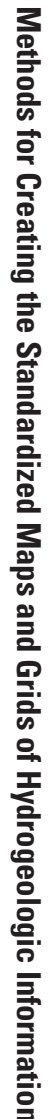


C

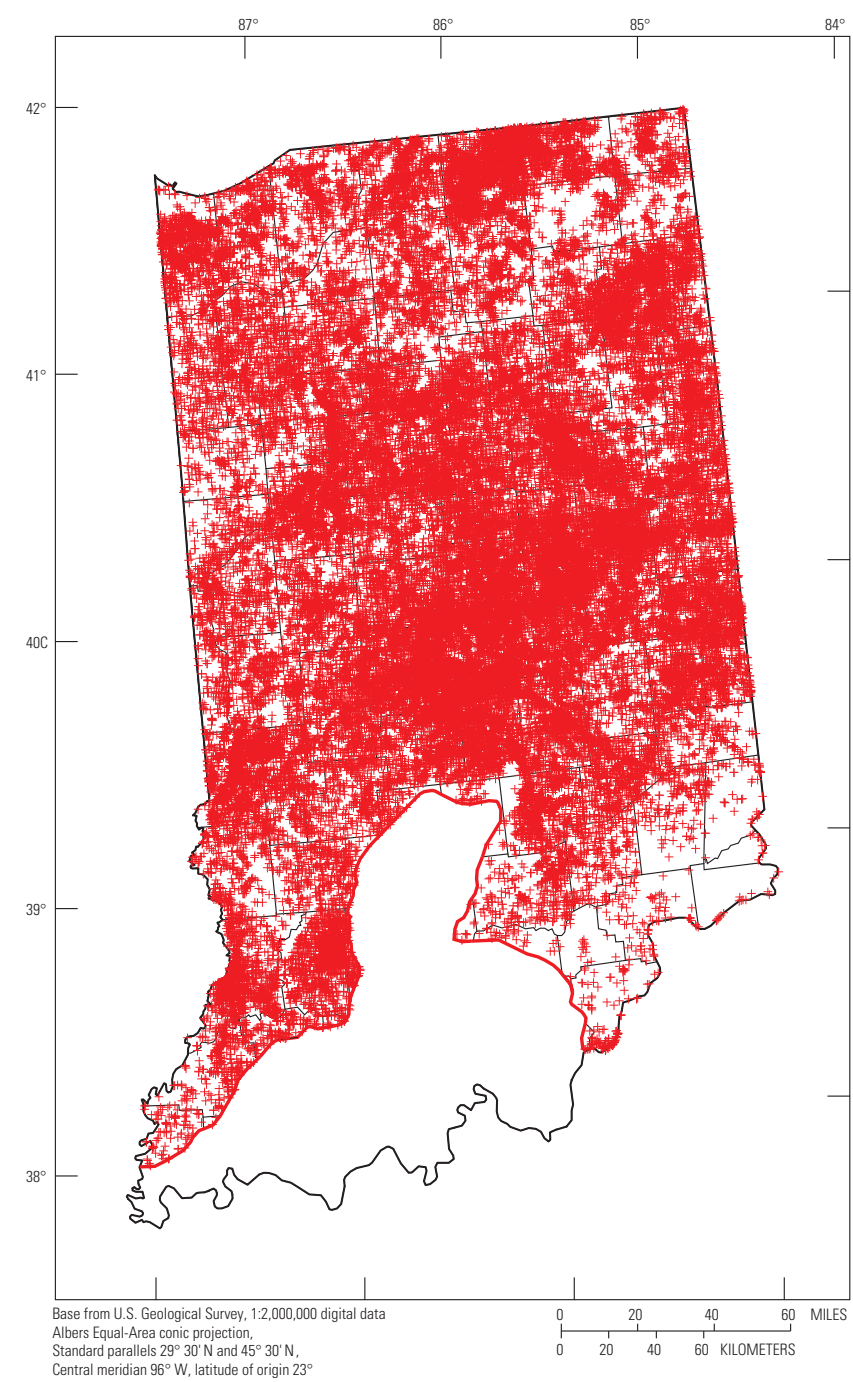

D

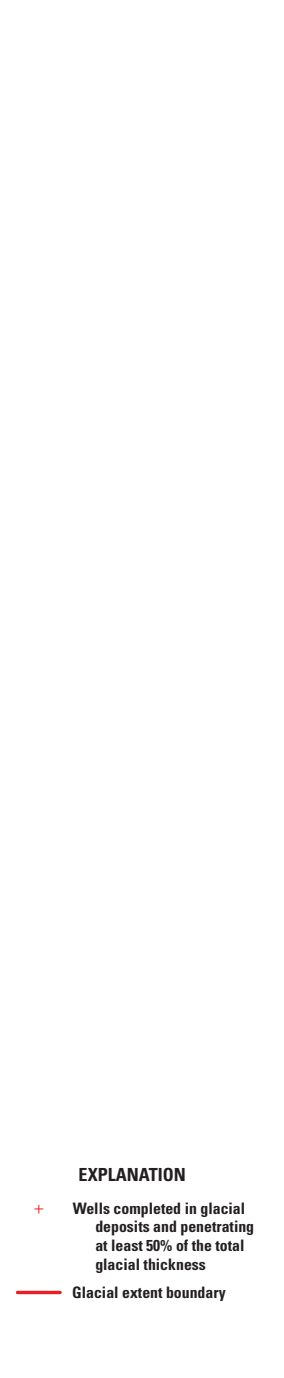

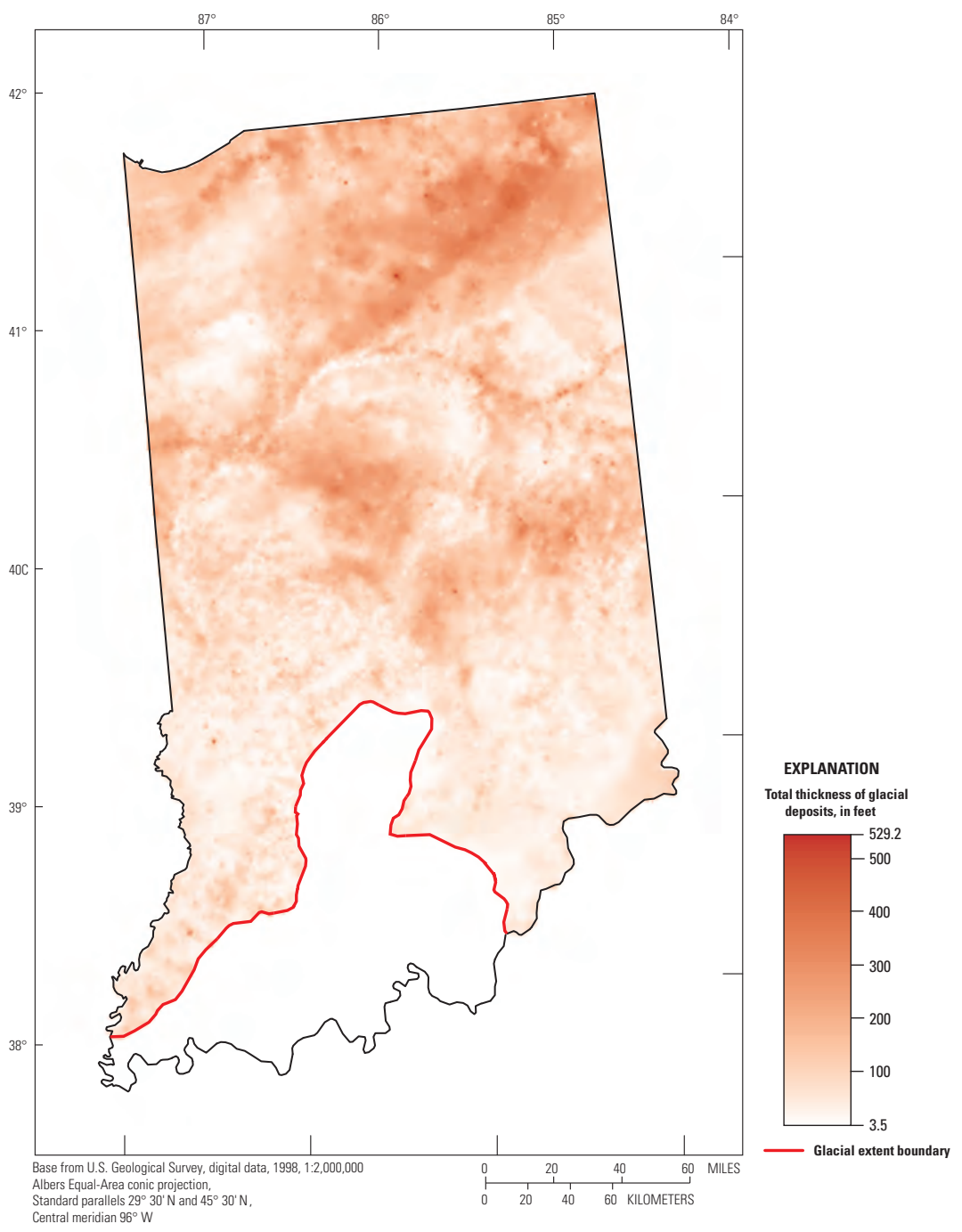

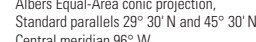

$\overrightarrow{+}$

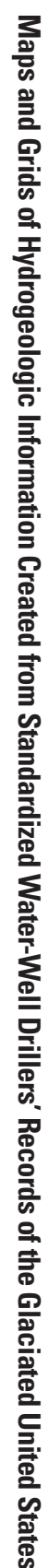

Figure $\mathbf{5} \boldsymbol{C}-\boldsymbol{D}$. Hydrogeologic information for Indiana as an example of State maps included in the nationwide mosaics. (Maps of hydrogeologic information for Indiana create

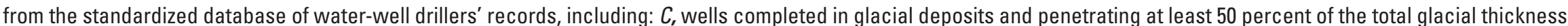
and $D$, total thickness of glacial deposits.) 

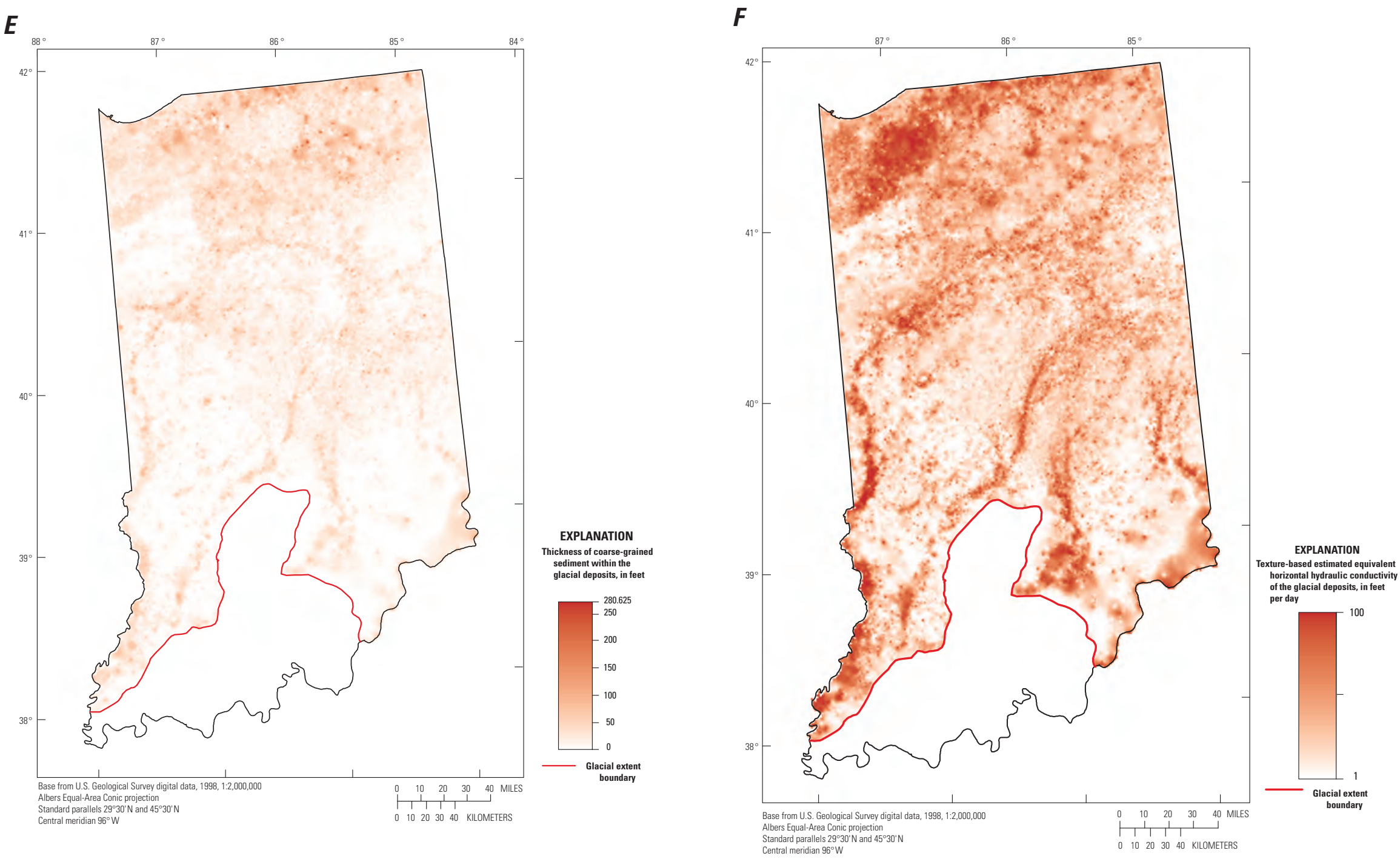

Figure $\mathbf{5} \boldsymbol{E}-\boldsymbol{F}$. Hydrogeologic information for Indiana as an example of State maps included in the nationwide mosaics. (Maps of hydrogeologic information for Indiana created from the standardized database of water-well drillers' records, including: $E$, thickness of coarse-grained sediment within the glacial deposits, and $F$, texture-based estimated equivalent horizontal hydraulic conductivity.) 

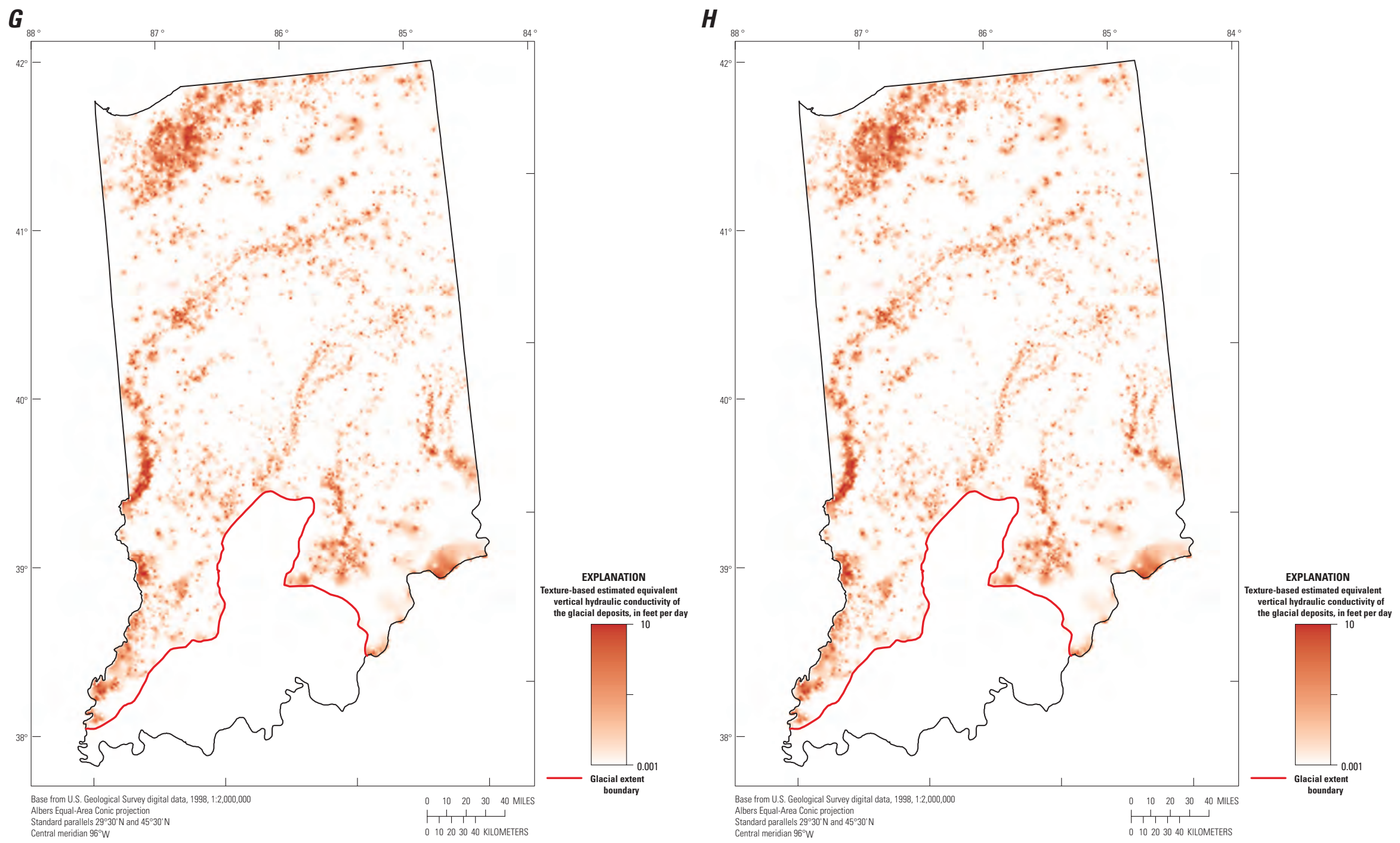

Figure $\mathbf{5} \mathbf{G}-\boldsymbol{H}$. Hydrogeologic information for Indiana as an example of State maps included in the nationwide mosaics. (Maps of hydrogeologic information for Indiana created from the standardized database of water-well drillers' records, including: $G$, texture-based estimated equivalent vertical hydraulic conductivity, and $H$, texture-based estimated equivalent transmissivity of the glacial deposits.) 

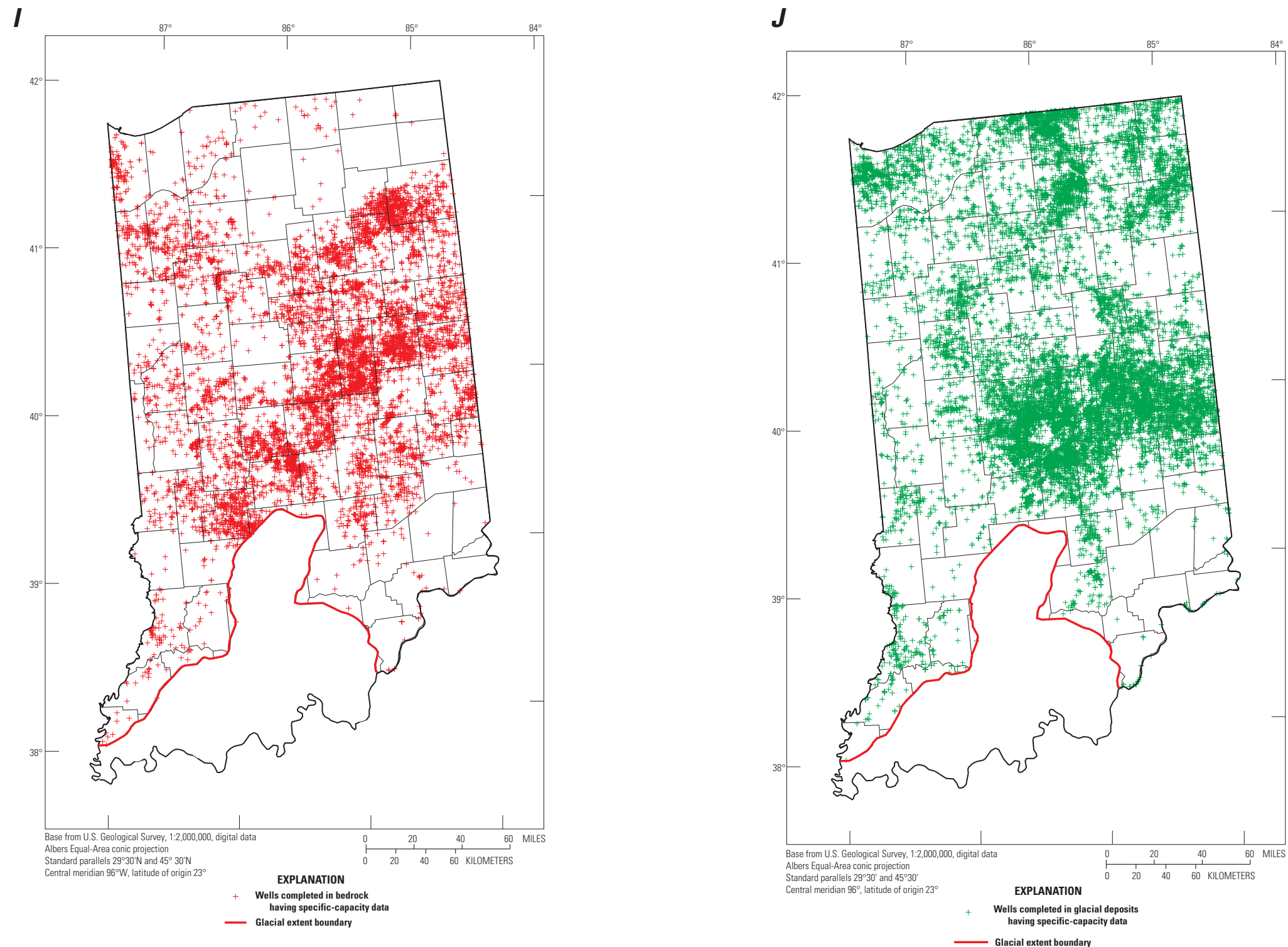

Figure $\mathbf{5}$ I-J. Hydrogeologic information for Indiana as an example of State maps included in the nationwide mosaics. (Maps of hydrogeologic information for Indiana created from the standardized database of water-well drillers' records, including: I, wells completed in bedrock having specific-capacity data, and $J$, wells completed in glacial deposits having specific-capacity data.) 
$\boldsymbol{K}$

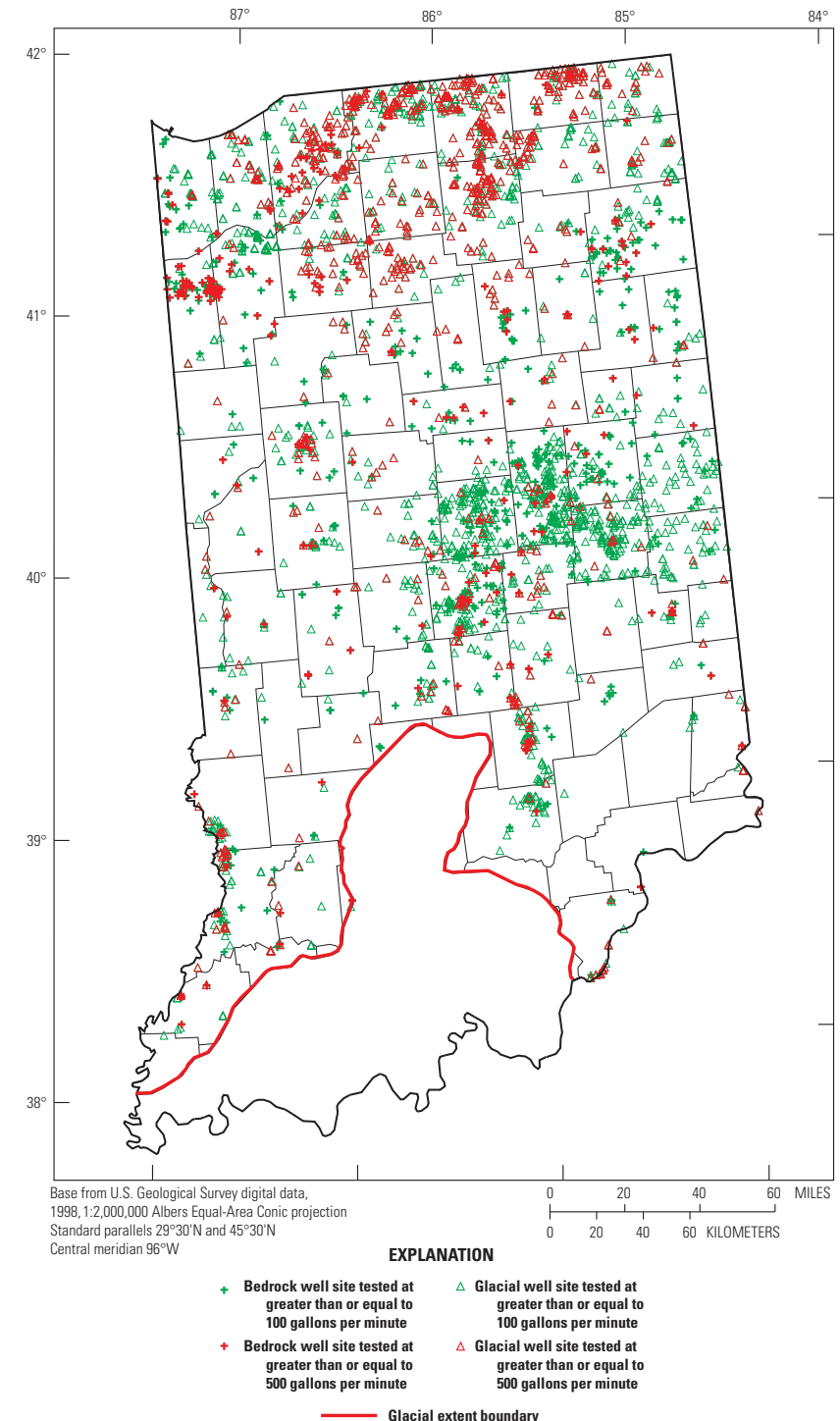

$L$

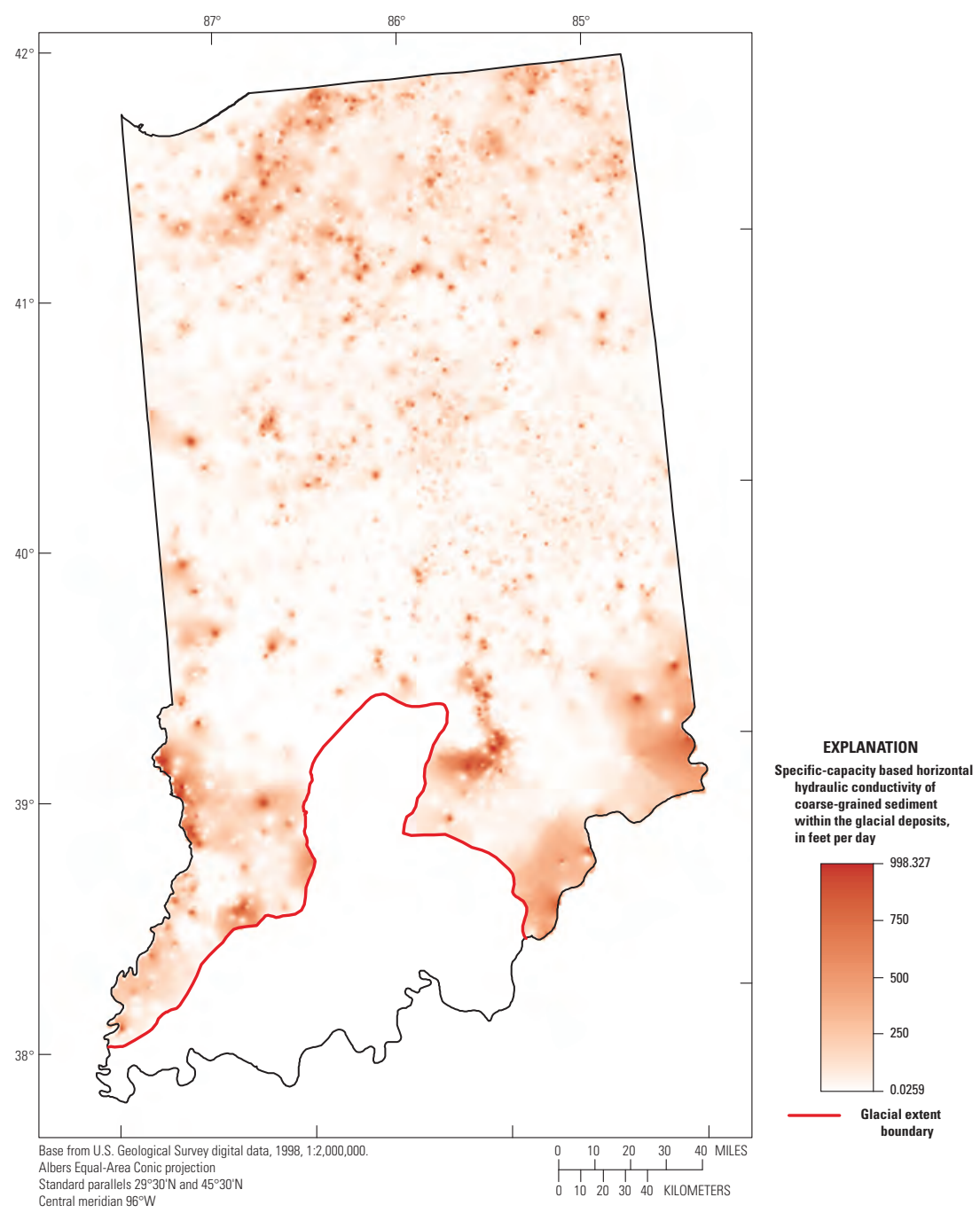

Figure $\mathbf{5} \boldsymbol{K}-\boldsymbol{L}$. Hydrogeologic information for Indiana as an example of State maps included in the nationwide mosaics. (Maps of hydrogeologic information for Indiana created from the standardized database of water-well drillers' records, including: $K$, wells completed in bedrock and glacial deposits withdrawing more than 100 and 500 gallons per minute, and $L$, specific-capacity based horizontal hydraulic conductivity of coarse-grained sediment within the glacial deposits.) 


\section{M}

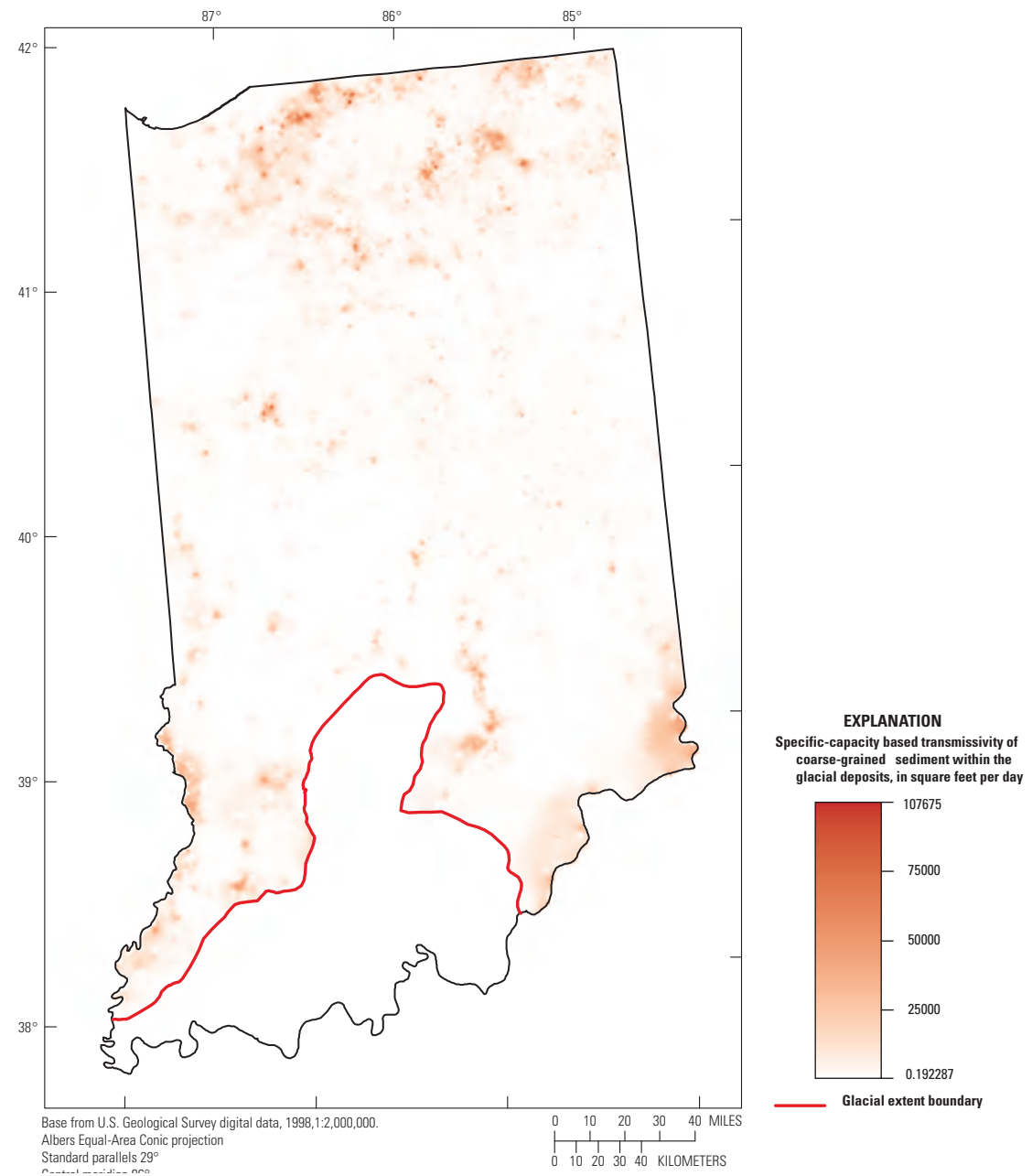

Figure $\mathbf{5} \boldsymbol{M}$. Hydrogeologic information for Indiana as an example of State maps included in the nationwide mosaics. (Maps of hydrogeologic information for Indiana created from the standardized database of water-well drillers' records, including: $M$, specific-capacity based transmissivity of coarse-grained sediment within the glacial deposits.) 


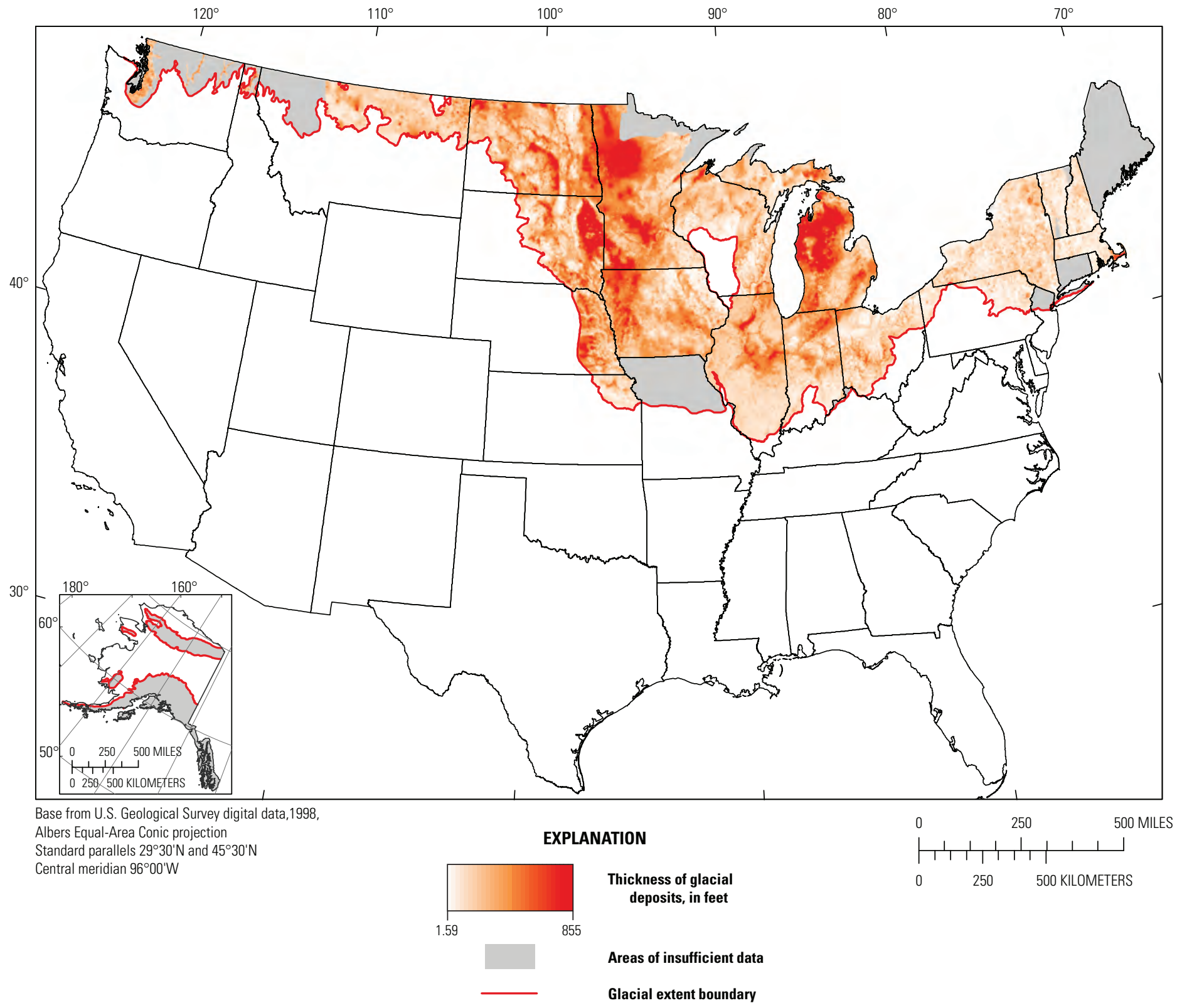

Figure 6. Thickness of glacial deposits in the United States. 


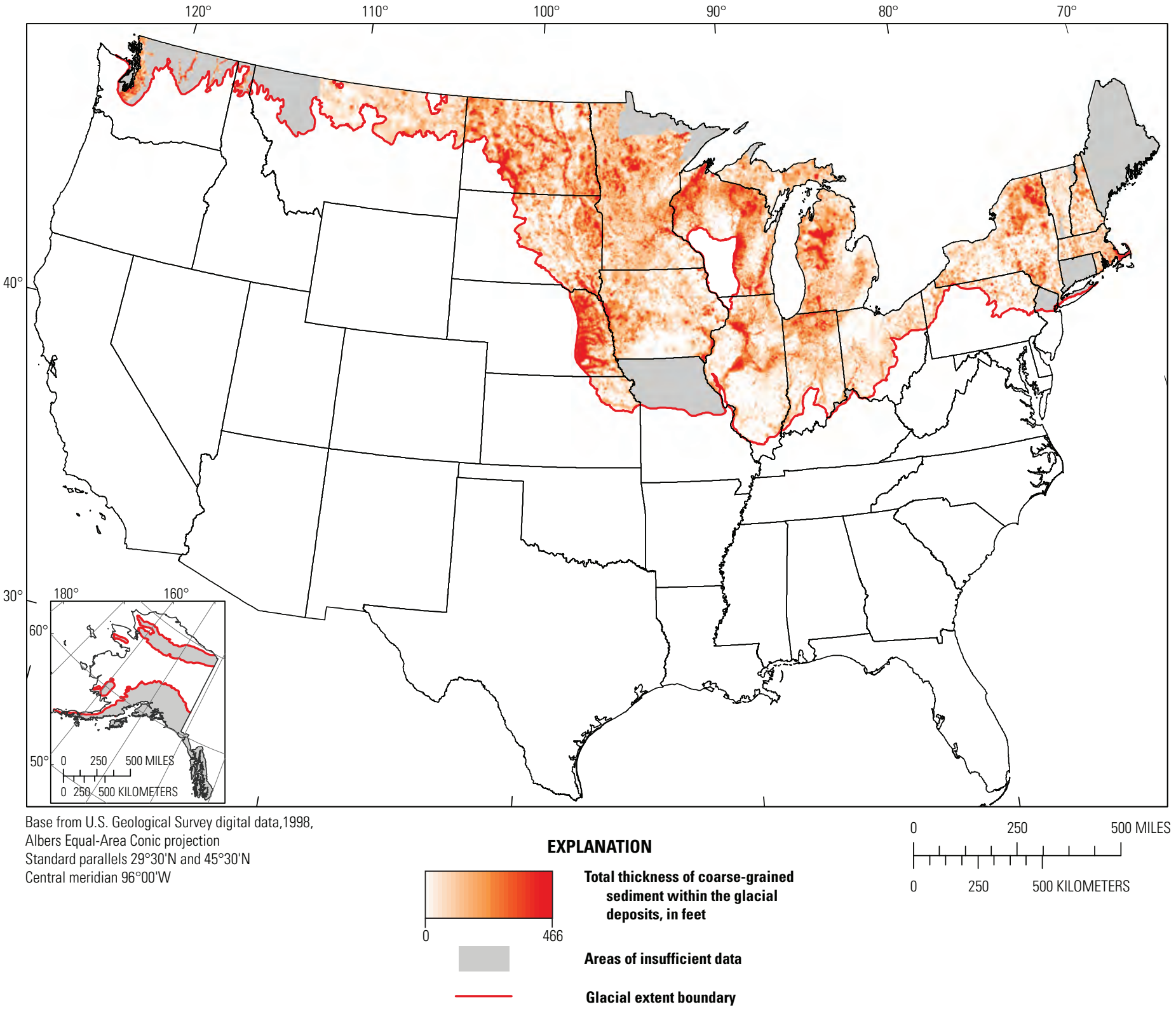

Figure 7. Total thickness of coarse-grained sediment within the glacial deposits of the United States. 


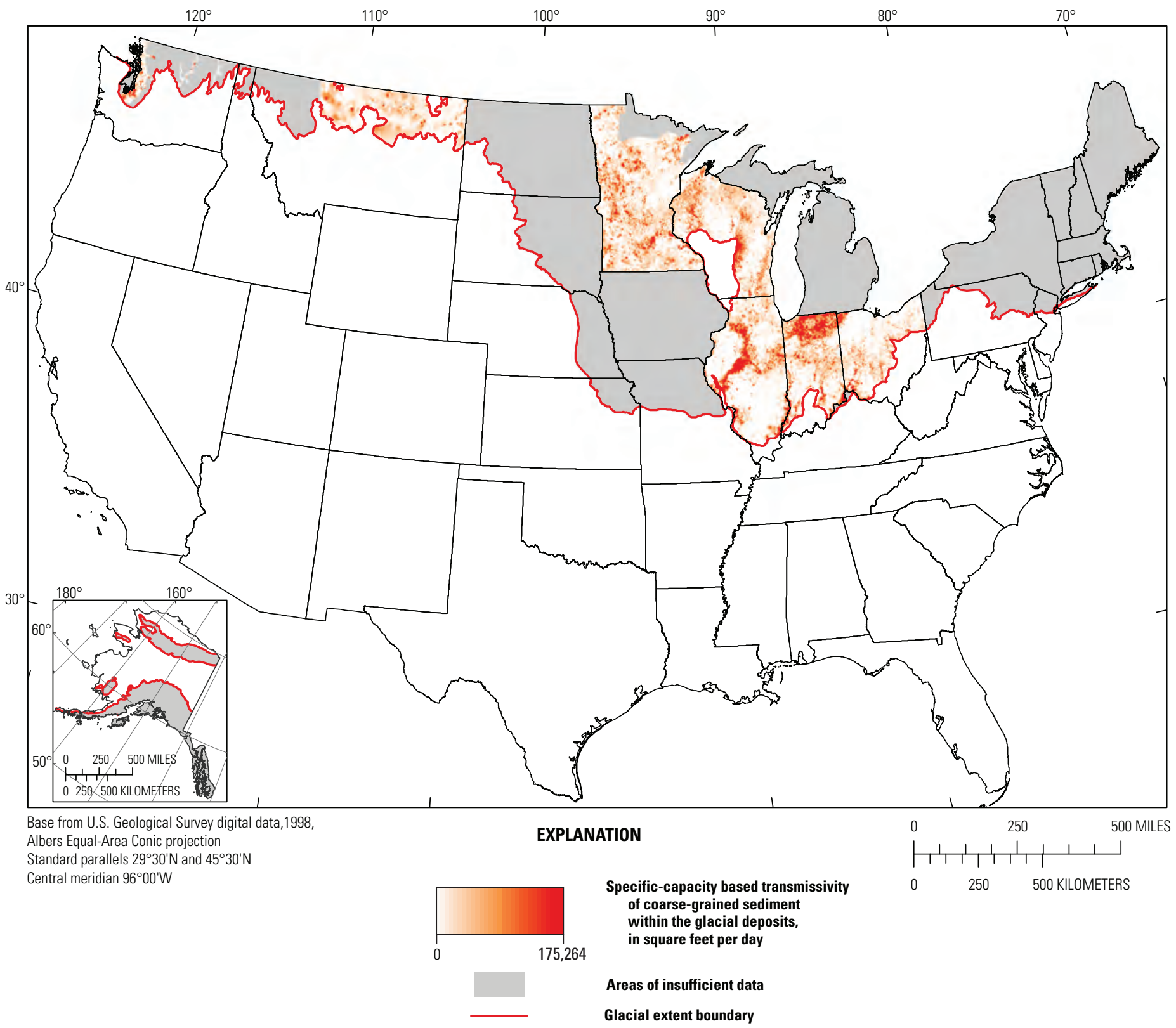

Figure 8. Specific-capacity based transmissivity of coarse-grained sediment within the glacial deposits of the United States. 


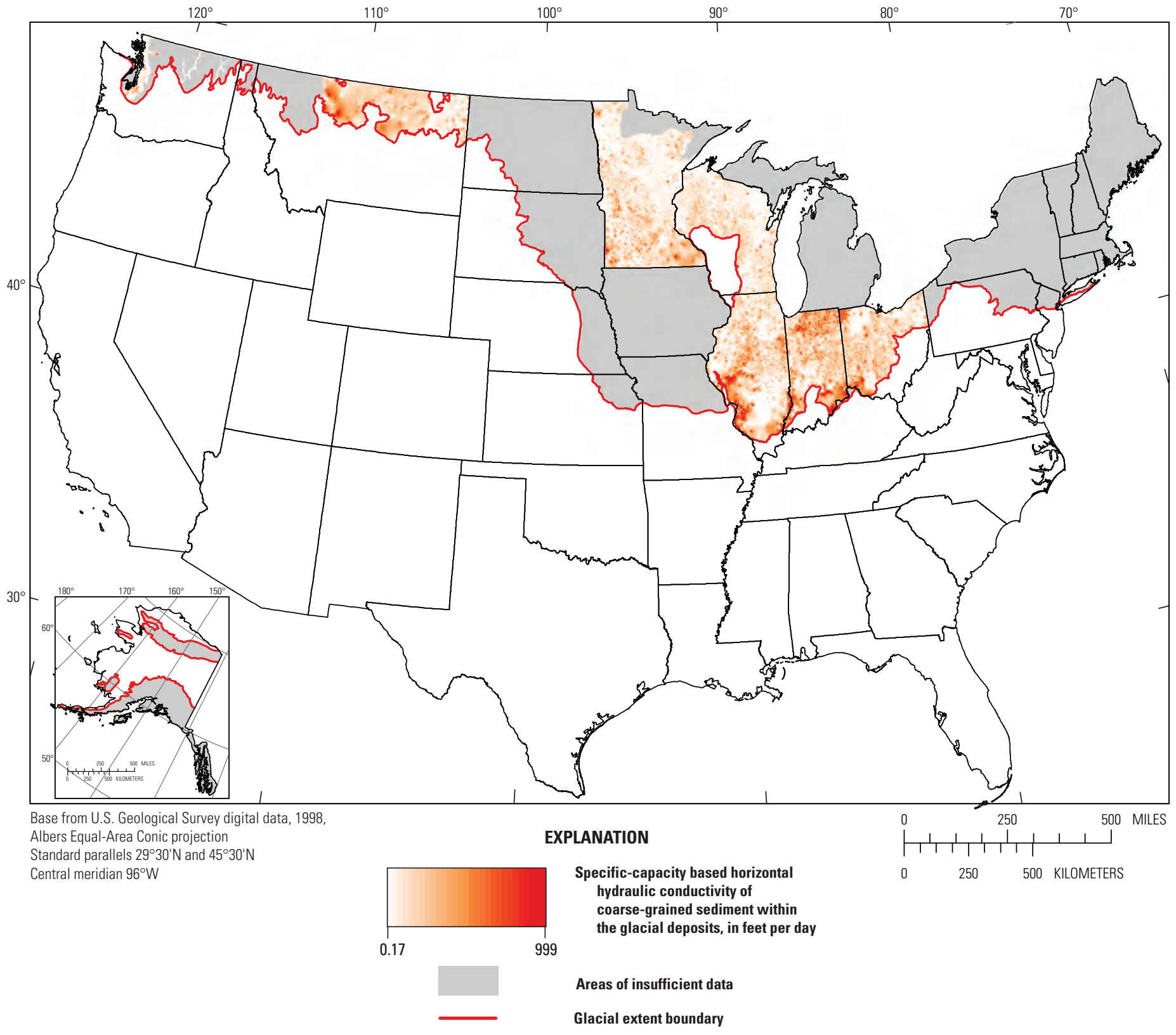

Figure 9. Specific-capacity based horizontal hydraulic conductivity of coarse-grained sediment within the glacial deposits of the United States. 


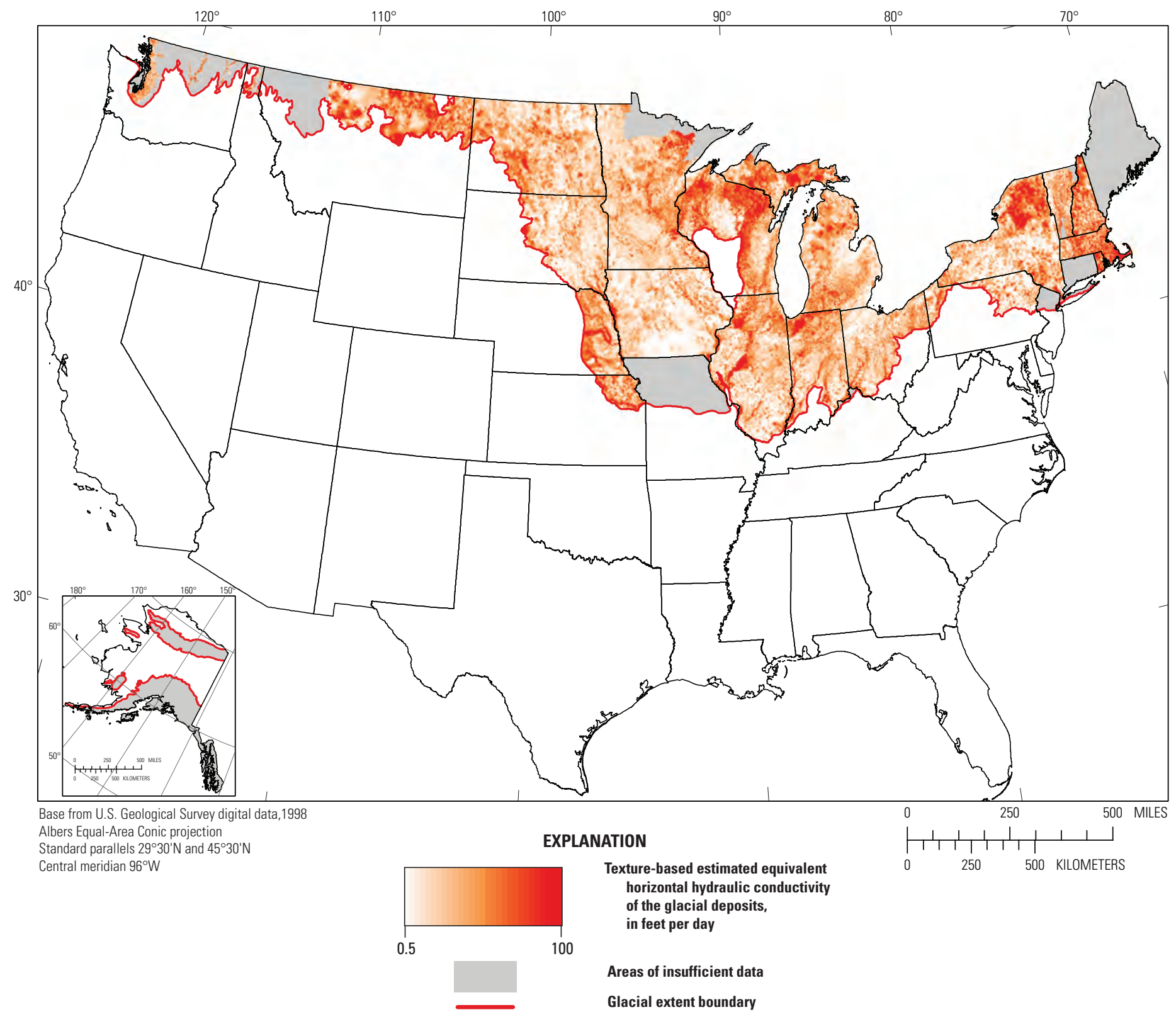

Figure 10. Texture-based estimated horizontal hydraulic conductivity of the glacial deposits of the United States. 


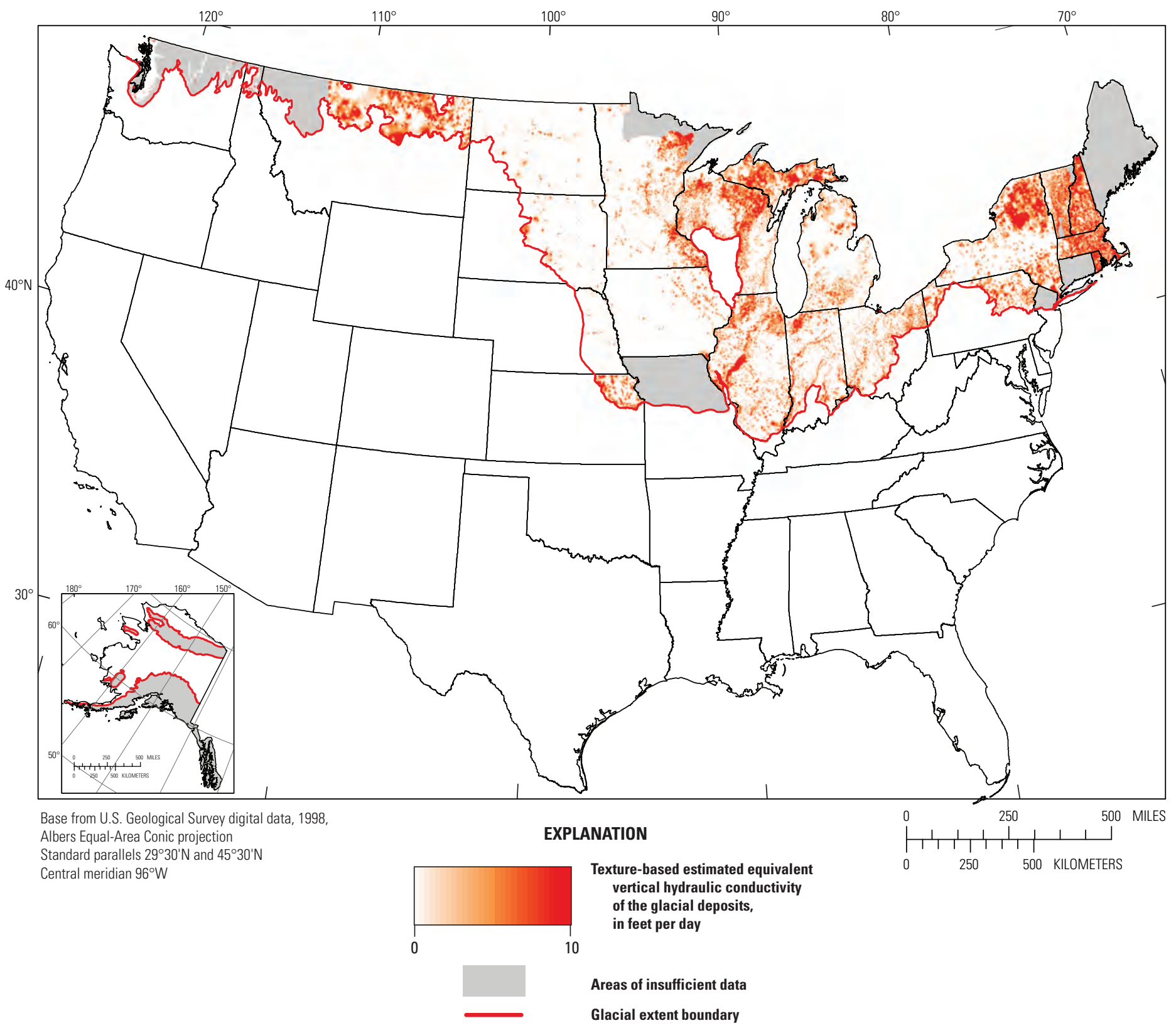

Figure 11. Texture-based estimated vertical hydraulic conductivity of the glacial deposits of the United States. 


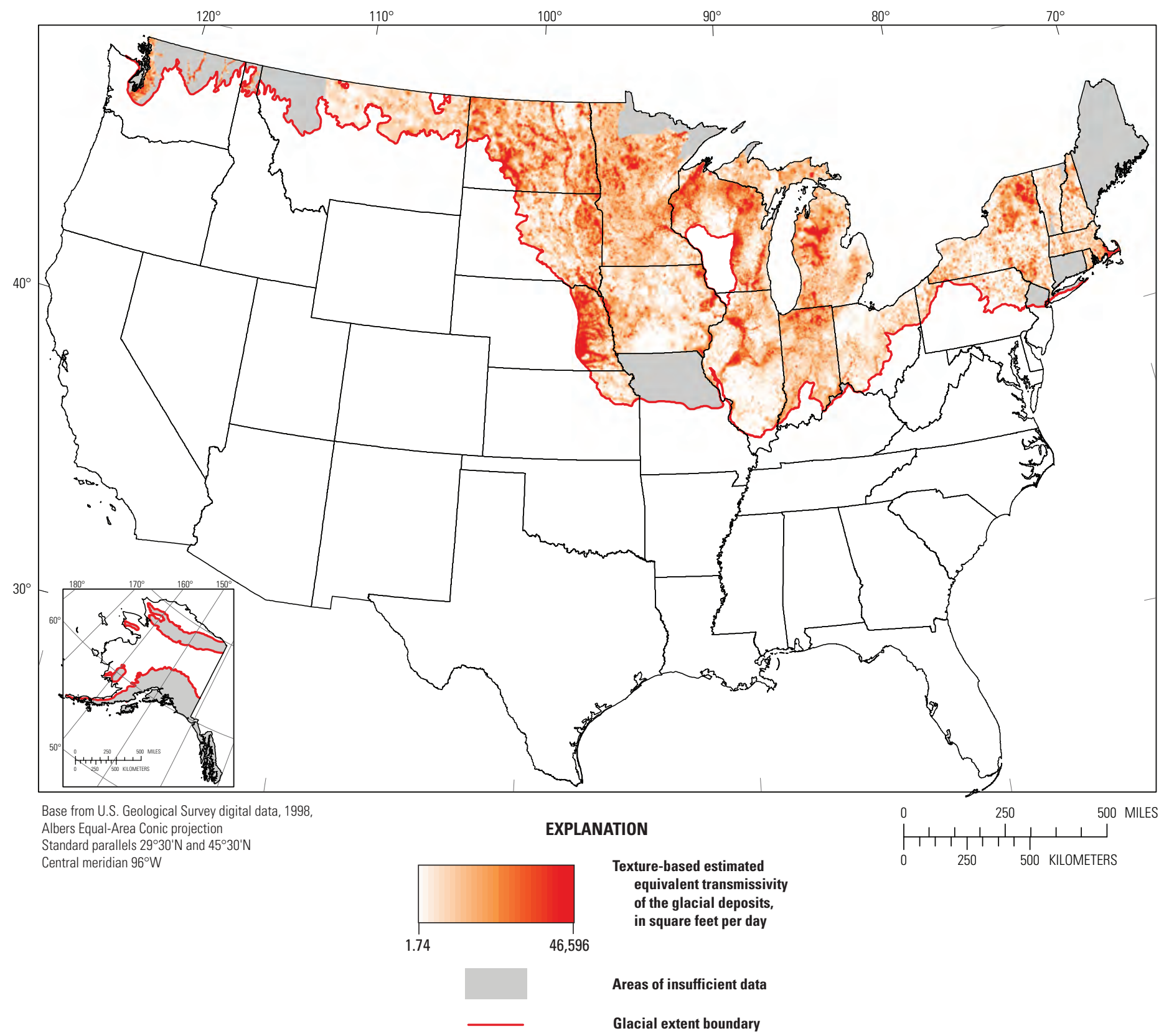

Figure 12. Texture-based estimated equivalent transmissivity of the glacial deposits of the conterminous United States. 


\section{Comparing Maps of Hydrogeologic Information with Maps from Other Studies}

The maps of hydrogeologic information that were created during this study by processing water-well drillers' records were compared with existing maps of the same or similar information to (1) qualitatively evaluate the accuracy of this study's results, (2) discover areas where the addition of the third dimension (well logs) uncovers geologic detail not discernable from surface features, (3) discover inaccuracies in the well-log data, and (4) discover inaccuracies in the well-log interpretation process. Whenever inaccuracies were discovered, records were deleted or AML programs and processing steps were improved.

\section{The Ground Water Atlas of the United States}

The Ground Water Atlas of the United States summarized available hydrogeologic information for the entire Nation using a common presentation format that included many maps (Miller, 1999). The maps and information in the Atlas were based on existing reports and files of the USGS and other agencies and often required combining multiple sources of information to cover the entire extent of the mapped regions. Those maps likely relied heavily on water-well drillers' records but also may have used some combination of geophysical information and well logs used for oil, gas, and mineral exploration. The application of common methods to waterwell drillers' records from the glaciated part of the Nation was a goal of this study, which made intercomparison with the Atlas a logical choice.

The maps of hydrogeologic information created during this study were routinely compared to maps of similar information shown in the Atlas. If discrepancies existed, they were investigated and adjustments were made if warranted. All things considered, the maps created during this study depicted the same spatial trends shown in the Atlas figures.

The comparisons indicated that the trends in major and minor geologic features were generally honored by the maps created during this study; however, the density of drillers' records was an important consideration in the resolution of minor geologic features in these maps. As examples, some maps for Illinois and Iowa are compared (herein) with maps of the same hydrogeologic information from the Atlas. About 197,000 water-well drillers' records were available, after the processing steps described in this study, to create the standardized maps and grids for Illinois. The density of drillers' records for the set of wells that penetrated more than 50 percent of the glacial deposit thickness was $2.37 \mathrm{wells} / \mathrm{mi}^{2}$. The map from this study showing the thickness of coarsegrained deposits was compared with the Atlas map showing surficial and buried aquifers in unconsolidated deposits in Illinois (Miller, 1999, fig. 4, p. K3) (figs. 13 and 14, respectively). The comparison shows significant deposits of sand and gravel representing buried aquifers and river alluvium in central and northcentral Illinois. The map of total thickness of glacial deposits generated during this study also compared favorably with the thickness map for Illinois in the Atlas (Miller, 1999, fig. 14, p. K6) (figs. 15 and 16, respectively). The maximum thickness shown in the Atlas is 400 to $600 \mathrm{ft}$, and the maximum thickness appearing on the map generated during this study is approximately $447 \mathrm{ft}$.

About 13,800 water-well drillers' records in Iowa were available for map construction after the processing steps described in this study. The map of total thickness of glacial deposits that was produced during this study was compared with the map of total thickness of unconsolidated deposits in Iowa depicted in the Atlas (Olcott, 1992, fig. 30, p. J9) (figs. 16 and 17, respectively). The comparison showed a similar distribution of the thickness of glacial deposits. In both maps, spatially extensive and thicker deposits occurred in the western part of the State and thinner deposits occurred along the eastern edge of the State. More spatially limited deposits, such as the thicker deposits in east-central Iowa, also appeared on both maps. The thickest deposits in the Atlas map were 400 to $600 \mathrm{ft}$ and compare favorably with a maximum thickness of $532 \mathrm{ft}$ in the map created during this study. The density of drillers' records in the maps shown for Iowa was about 0.25 records per square mile after standardization, error removal, and eliminating logs that penetrated less than 50 percent of the total thickness of glacial deposit. This relatively low density of drillers' records was counterbalanced by the even distribution of the logs and deposits across the State.

The map of coarse-grained deposits generated during this study was compared with the distribution of surficial glacial sediments that appears in the Atlas for Iowa (Olcott, 1992, fig. 6, p. J3) (figs. 19 and 20, respectively). As discussed in Arihood (2009), some surficial deposits are good indicators of the nature of sediments at greater depth, such as those along the Missouri and Cedar Rivers. Most surficial sand and gravel deposits shown in the Atlas, however, are not indicative of the total thickness of sand and gravel that appears in the map created during this study; examples of this are the relatively thick sand and gravel deposits in eastern Iowa. 


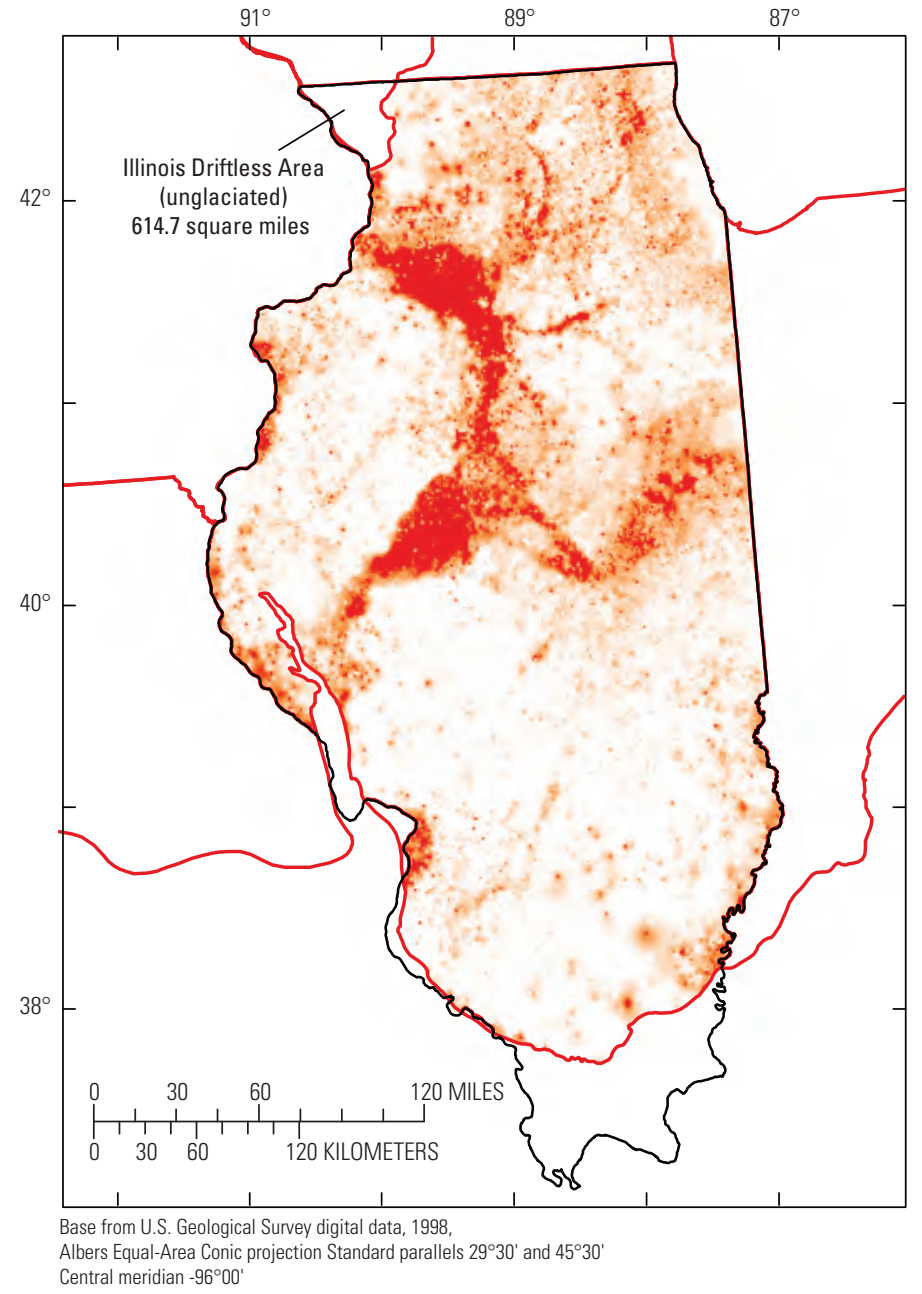

EXPLANATION

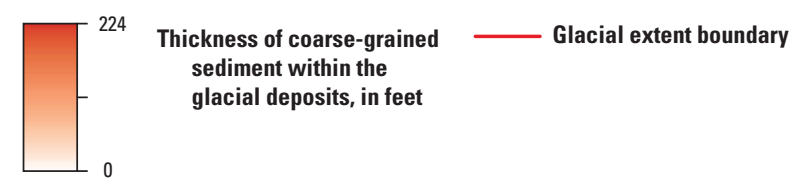

Figure 13. Map created during this study showing the total thickness of coarse-grained sediment within the glacial deposits in Illinois.

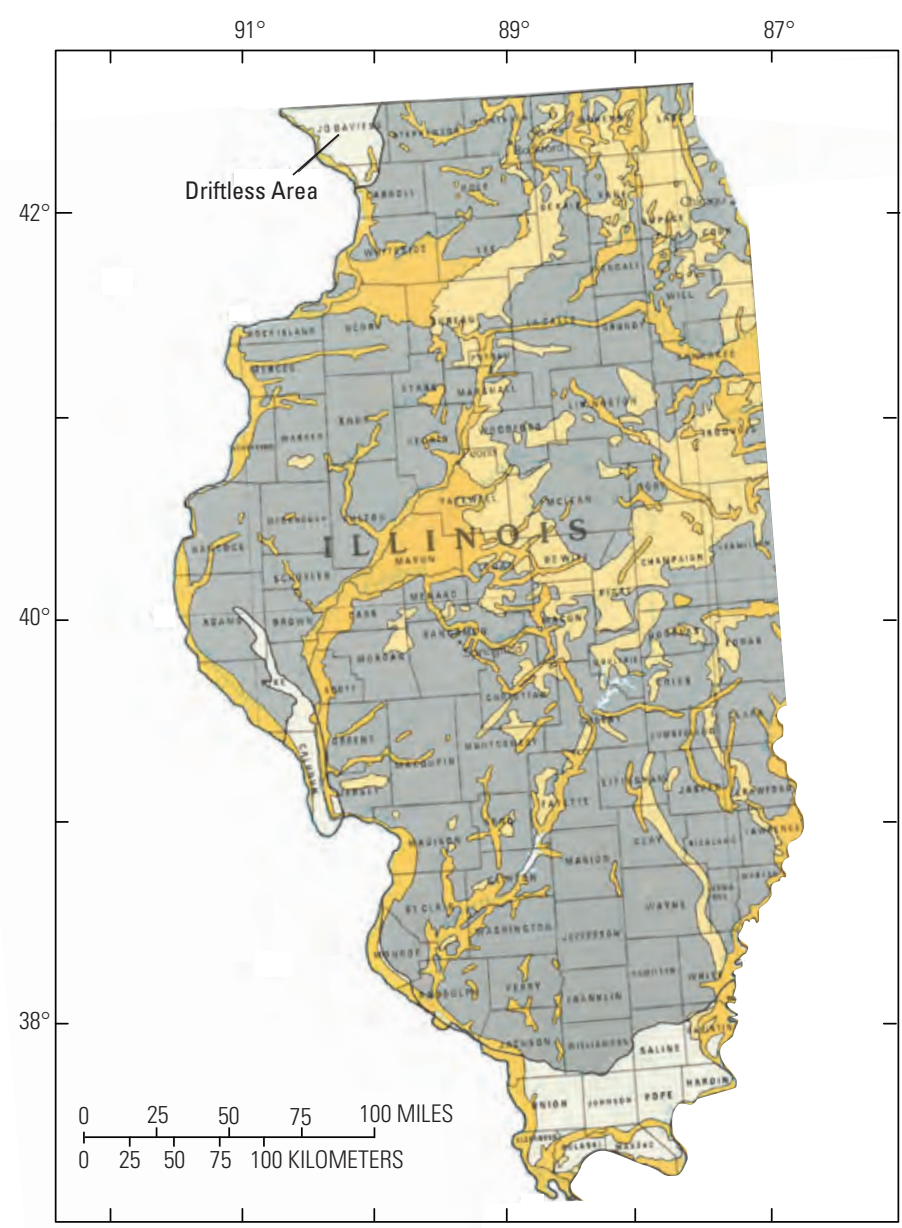

Base modified from U.S. Geological Survey digital data, 1:2000,000, 1972

Albers Equal-Area Conic projection, Standard parallels $29^{\circ} 30^{\circ}$ and $45^{\circ} 30^{\prime}$.

\section{EXPLANATION}

Sand and gravel aquifers at or near land surface, and alluvium along streams and rivers-Patterned area shows Mississippi River Valley alluvium aquife

Surficial deposits generally less than 100 feet thick, and the occurrence of sand and gravel aquifers diticult to

\section{Sand and gravel aquifers buried}

Southern limit of glaciation beneath finer grained material

Figure 14. Map from the Ground Water Atlas (Miller, 1999, fig. 4, p. K3) showing surficial and buried aquifers in unconsolidated deposits in Illinois. 
$91^{\circ}$

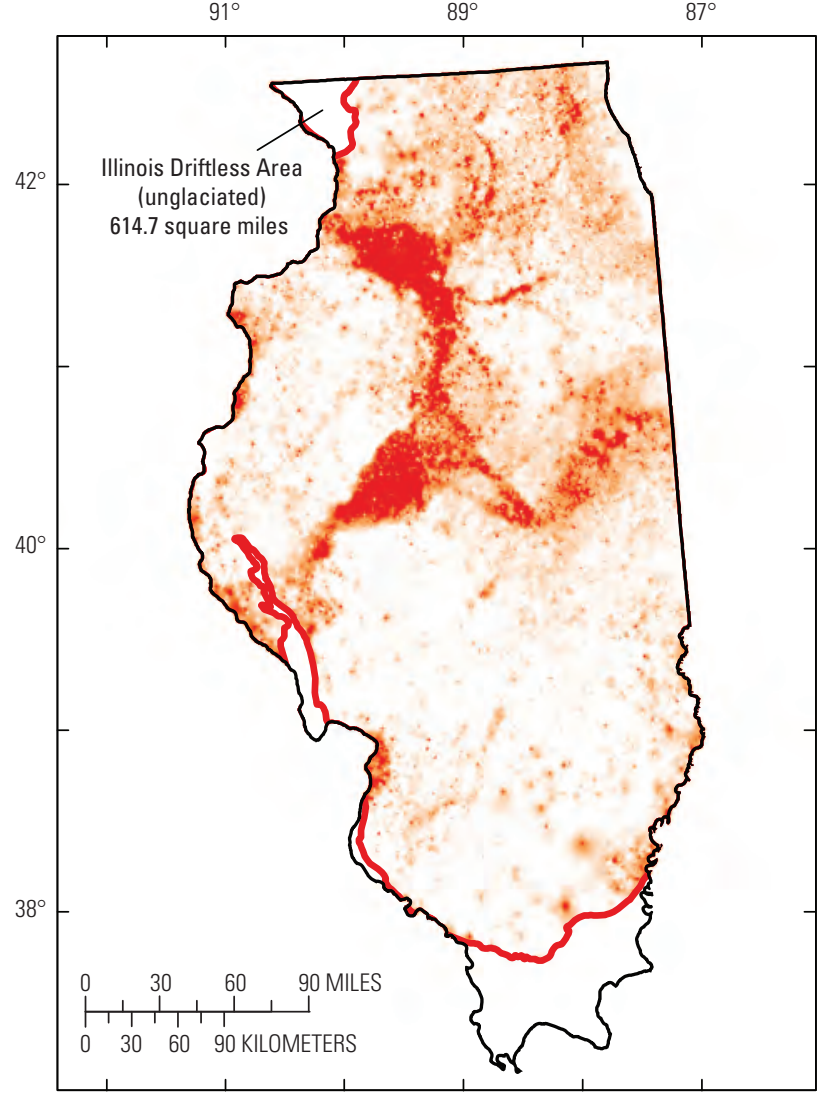

Base from U.S. Geological Survey digital data, 1998, Albers Equal-Area Conic projection Central meridian $-96^{\circ} 00^{\prime}$

\section{EXPLANATION}

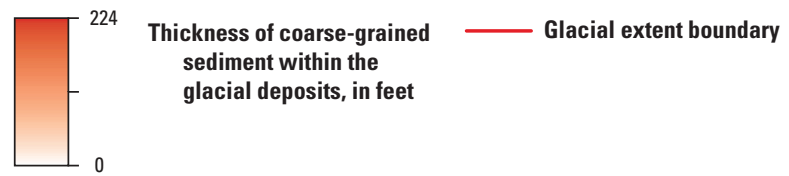

Figure 15. Map created during this study showing the thickness of glacial deposits in Illinois.

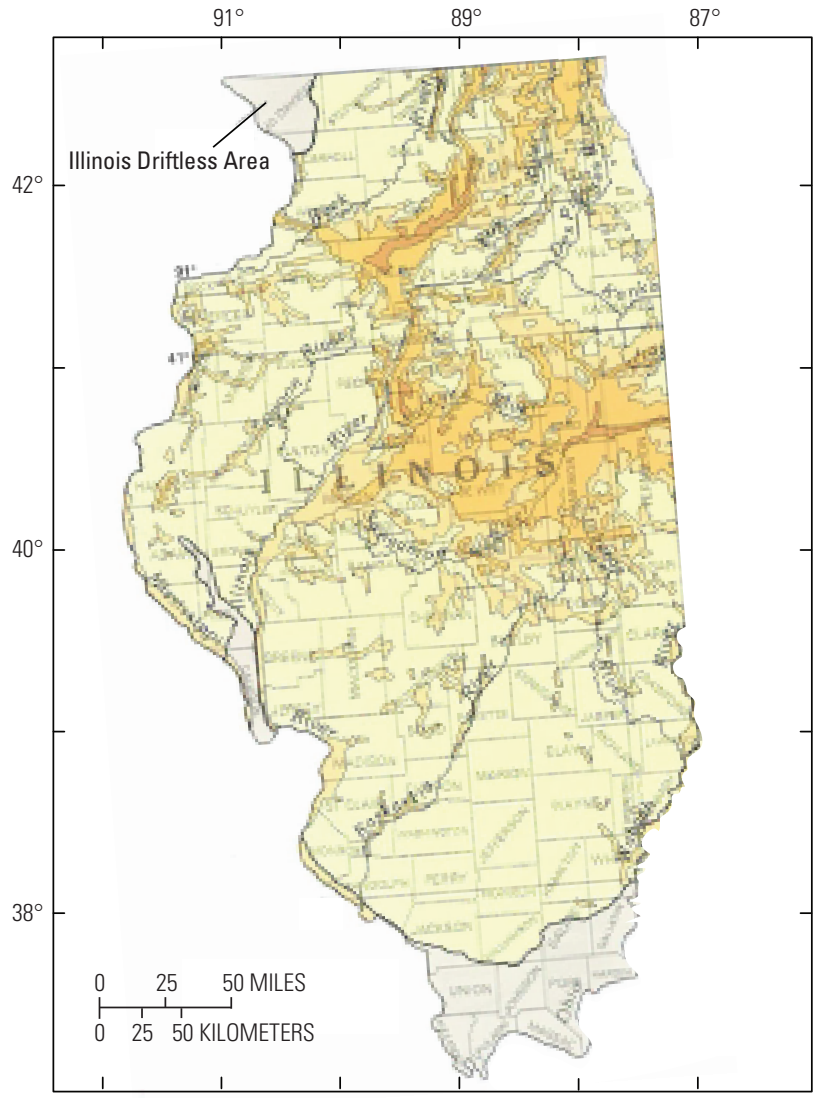

Base modified from U.S. Geological Survey digital data, 1:2000,000, 1972 Albers Equal-Area Conic projection Standard parallels $29^{\circ} 30^{\circ}$ and $45^{\circ} 30^{\circ}$. Central meridian $-96^{\circ} 00^{\circ}$

\section{EXPLANATION}

\section{Thickness of Quaternary deposits, in feet}

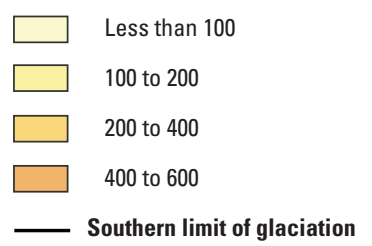

Figure 16. Map from the Ground Water Atlas (Miller, 1999, fig. 14, p. K6) showing the thickness of glacial deposits in Illinois. 


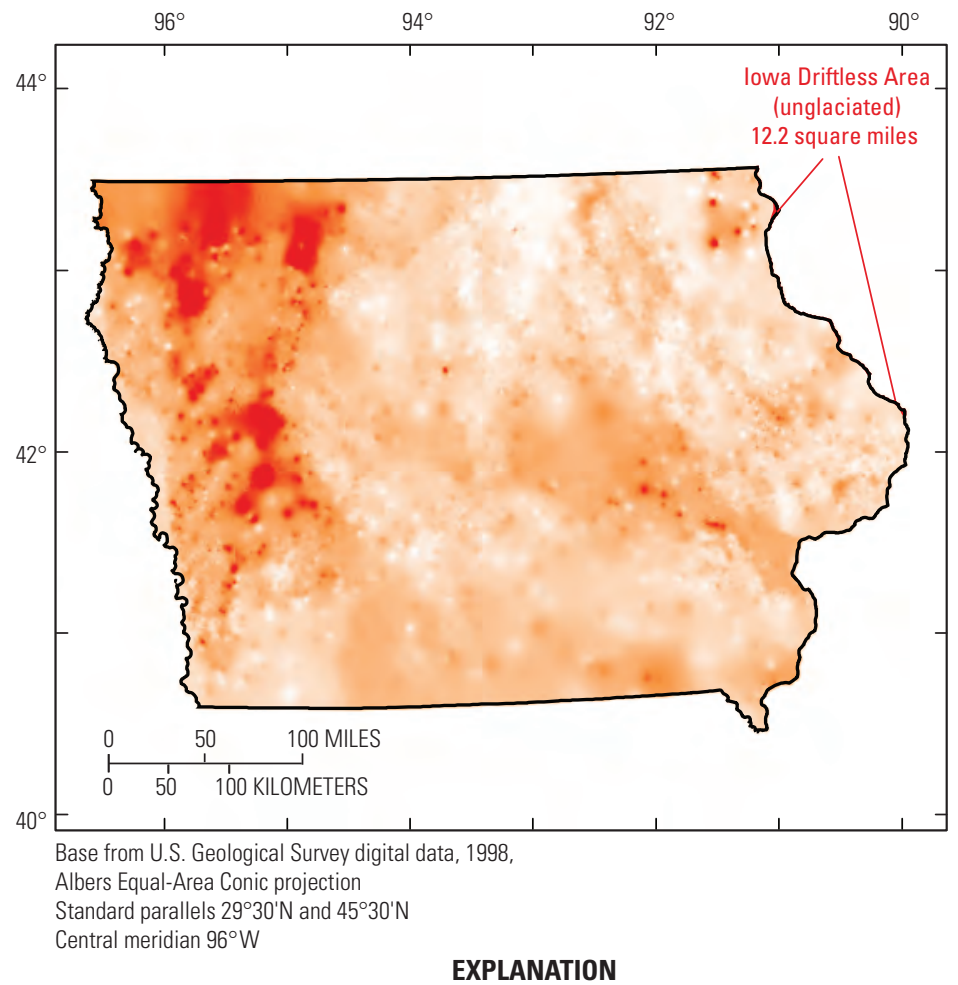

Total thickness of glacial deposits, in feet

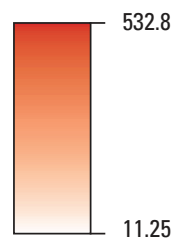

Figure 17. Map created during this study showing the thickness of glacial deposits in lowa.

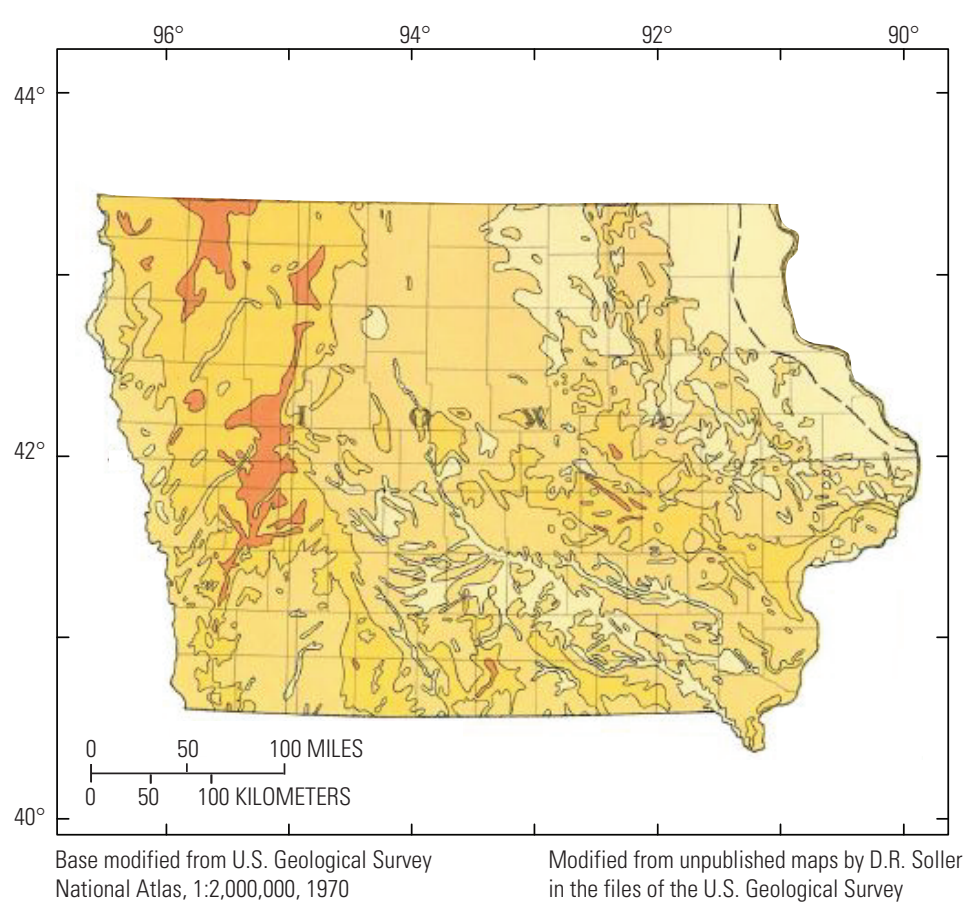

\section{EXPLANATION}

\section{Thickness of glacial deposits, in feet}

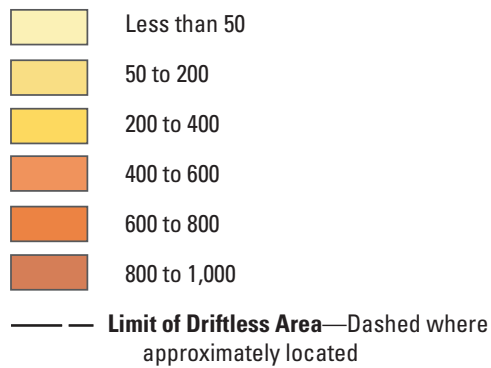

approximately located

Figure 18. Map from the Ground Water Atlas (Olcott, 1992, fig. 30, p. J9) showing the thickness of glacial deposits in lowa. 


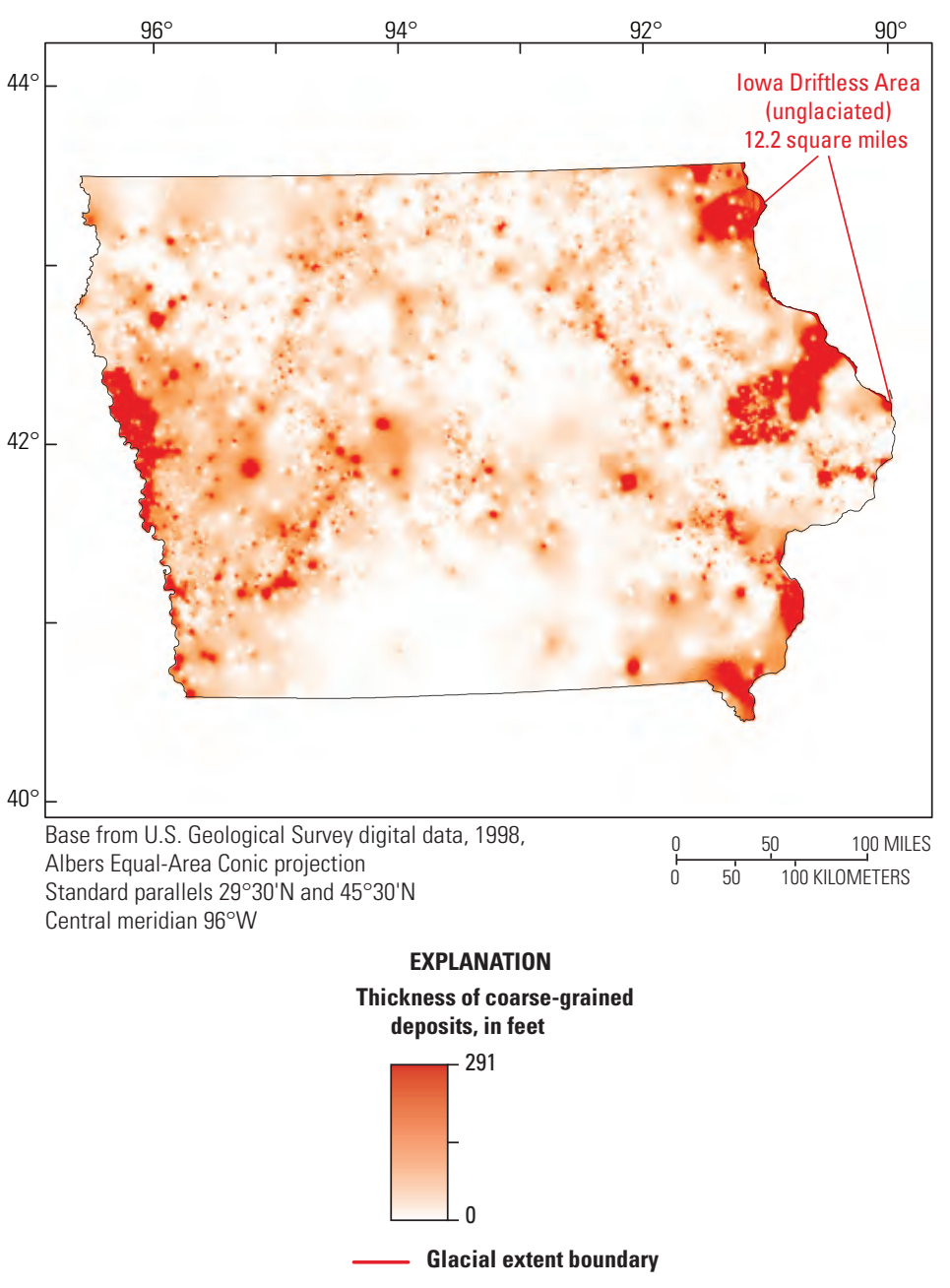

Figure 19. Map created during this study showing the total thickness of coarse-grained sediment within the glacial deposits in lowa.

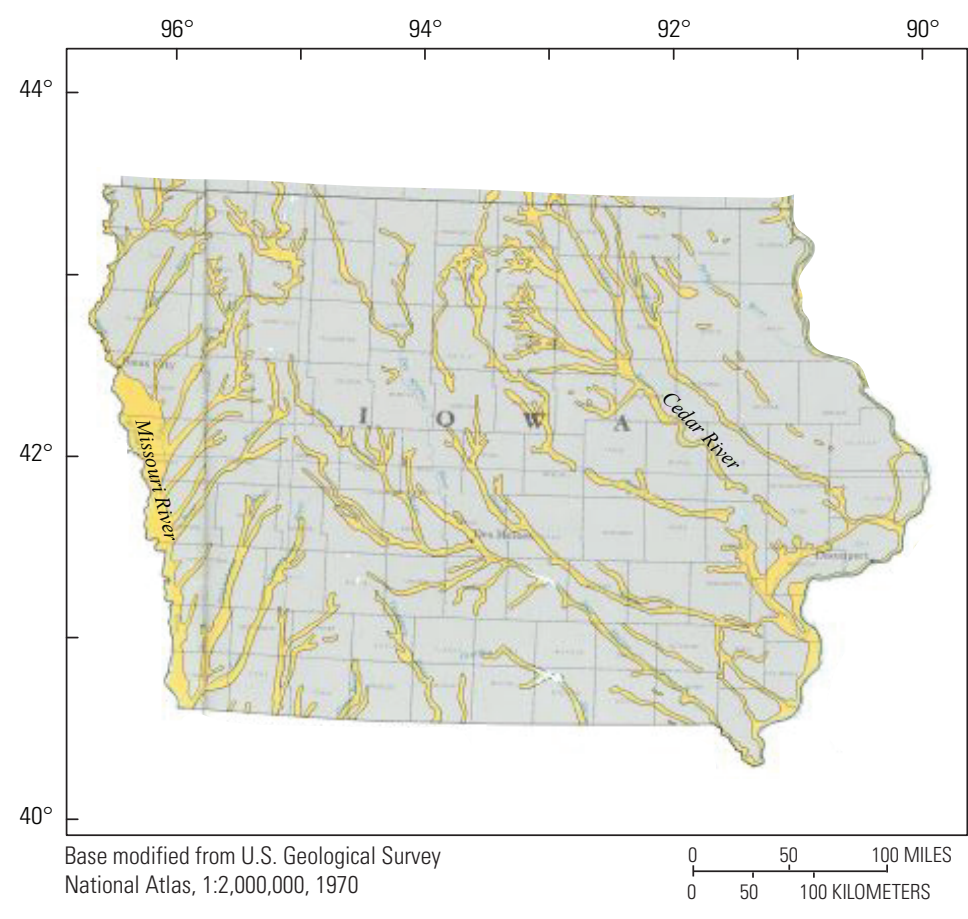

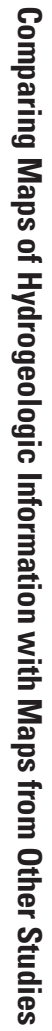

. showing the distribution of coarse-grained sediment within the glacial deposits in lowa. 


\section{Williston Basin Groundwater Availability Study}

The USGS Groundwater Resources Program examined groundwater use and availability in the Williston and Powder River Basins (Reilly and others, 2008). The hydrogeologic framework and related maps produced for the Williston and Powder River structural basins provided an opportunity to compare maps of hydrogeologic information created during that study (Thamke and others, 2014) with maps of similar information created during this study. The maps for the groundwater availability study in the Williston and Powder River Basins were created by synthesizing available information that included many publications, water-well drillers' records, and geophysical information. These maps were used to improve understanding of the regional hydrogeologic framework and to support the construction of groundwaterflow models. The study area included parts of North Dakota, Montana, Saskatchewan, and Manitoba.

The map of total thickness of glacial deposits produced during this study was compared with the same information generated by the groundwater availability study for the Willison and Powder River Basins (figs. 21 and 22, respectively). In general, the absolute difference between the thickness of glacial deposits in both maps was less than $25 \mathrm{ft}$. The densities of post-processing drillers' records in North Dakota was 0.22 wells $/ \mathrm{mi}^{2}$.

\section{Potential Uses of the Maps and Grids of Hydrogeologic Information}

There are many potential uses for the standardized maps and grids of hydrogeologic information. The gridded datasets of hydrogeologic information, particularly horizontal and vertical hydraulic conductivity, might be used in examining aquifer vulnerability, surface-water low-flow characteristics, groundwater/surface-water interaction, and groundwater recharge. Maps showing the thickness of coarse-grained deposits and total thickness of glacial deposits might be used for estimating groundwater storage.

\section{Limitations of the Maps of Hydrogeologic Information}

The application of maps and grids of hydrogeologic information produced during this study to future hydrologic investigations should consider (1) the accuracy of the waterwell drillers' records used to construct the standardized maps and grids, (2) the methods used to process the drillers' records into the maps and grids, and (3) the density and spatial distribution of the water-well drillers' records. The Ground Water Atlas of the United States (Miller, 1999) recommended that the small-scale maps shown in that report not be used for "local information or site-specific interpretations" (p. A3). In this study, the maps of hydrogeologic information are interpolated between the well-record locations using numerical methods. The applicability of these maps to large-scale studies should be evaluated based on the density of drillers' records in the vicinity of the target area and the users' confidence in the interpolation method relative to the geologic setting.

The interpretation of the drillers' descriptions into GWSIcompatible names were spot-checked. Time constraints did not allow an inspection of all interpretations; therefore, a limited number of errors probably exist in the information used to construct maps and grids. Those errors are likely a small proportion of the entire lithologic record and do not substantially influence the outcomes expressed in the maps and grids. In areas of low local drillers' record density, however, a few wells with incorrect lithologic interpretation could locally dominate the values represented in the maps and grids.

The user of values appearing in maps and grids of the texture-based estimated equivalent of hydraulic conductivity and transmissivity should be aware that those are not absolute values, nor is the relative difference between the coarse and fine end-members, because no aquifer-test evaluations were done to derive the estimated values. The range of hydraulic conductivity values used to compute the texture-based estimated equivalent of hydraulic conductivity for the entire thickness of glacial deposits was selected to be generally representative of values that could be expected for those geologic deposits. The values in the maps and grids of texture-based estimated equivalent hydraulic conductivity and transmissivity, however, may be re-scaled for applications to areas where measured values of aquifer properties are available for scaling purposes. 

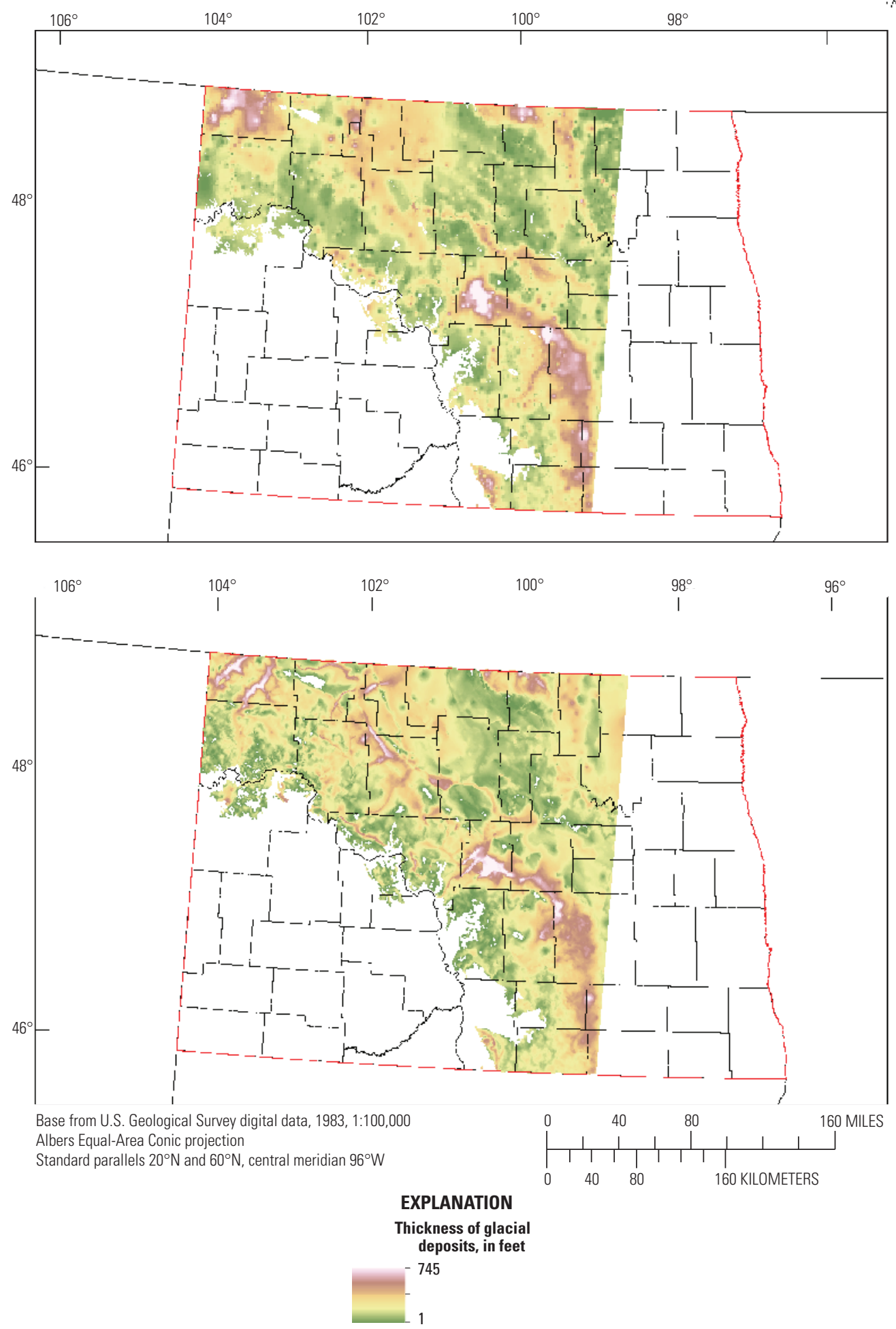

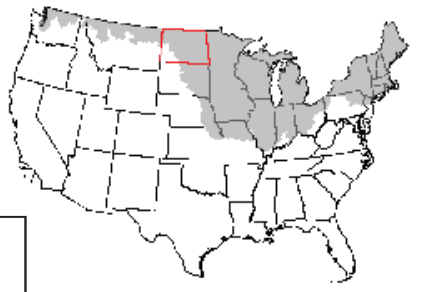

Figure 21. Map created during this study showing the thickness of glacial deposits in the part of North Dakota modeled by Thamke and others (2014).

Figure 22. Map showing the thickness of glacial deposits in North Dakota created by Thamke and others (2014). 


\section{References Cited}

Arihood, L.D., 2009, Processing, analysis, and general evaluation of well-driller records for estimating hydrogeologic parameters of the glacial sediments in a ground-water flow model of the Lake Michigan Basin: U.S. Geological Survey Scientific Investigations Report 2008-5184, 26 p. [Also available at http://pubs.usgs.gov/sir/2008/5184/.]

Bayless, E.R., Arihood, L.D., and Sperl, B.J., 2017, Maps and grids of hydrogeologic information created from standardized water-well drillers' records of the glaciated United States: U.S. Geological Survey data release, https://doi.org/10.5066/ F7BR8QCZ.

Berg, R.C., and Kempton, J.P., 1988, Stack-unit mapping of geologic materials in Illinois to a depth of 15 meters: Illinois State Geological Survey Circular 542, 4 pl., accessed January 20, 2015, at http://www.isgs.illinois.edu/publications/c542.

Feinstein, D.T., Hunt, R.J., and Reeves, H.W., 2010, Regional groundwater-flow model of the Lake Michigan Basin in support of Great Lakes Basin water availability and use studies: U.S. Geological Survey Scientific Investigations Report 2010-5109, 379 p., accessed March 17, 2015, at http://pubs. usgs.gov/sir/2010/5109/.

Flint, R.F., Alden, W.C., Apfel, E.T., Bostock, H.S., Capps, S.R., Goldthwait, J.W., Gould, L.M., Kay, G.F., Leighton, M.M., Leverett, Frank, MacClintock, Paul, Nichols, D.A., Norman, H., Thwaites, F.T., White, G.W., and Young, G.A., 1945, Glacial map of North America: Geological Society of America, Special Paper no. 60, scale 1:4,555,000.

Mathey, S.B., ed., 1989, National water information system user's manual, v. 2, chap. 4., Ground-Water Site Inventory System: U.S. Geological Survey Open-File Report 89-587, $281 \mathrm{p}$.

Maupin, M.A., and Barber, N.L., 2005, Estimated withdrawals from principal aquifers in the United States, 2000: U.S. Geological Survey Circular 1279, 46 p. [Also available at http://pubs.usgs.gov/circ/2005/1279/.]

Miller, J.A., 1999, Ground Water Atlas of the United StatesIntroduction and National Summary, chap. A: U.S. Geological Survey Hydrologic Atlas 730, 15 p., accessed January 11, 2015, at http://pubs.usgs.gov/ha/ha730/ch_a/fullpgPDF.html.

National Science and Technology Council, 2007, A strategy for Federal science and technology to support water availability and quality in the United States, 35 p., accessed December 29, 2014, at https://www.acs.org/content/dam/acsorg/policy/ acsonthehill/briefings/energywaternexus/nstc-09-07-fed-stfor-water-quality.pdf.
Olcott, P.G., 1992, Ground Water Atlas of the United States, Iowa, Michigan, Minnesota, Wisconsin: U.S. Geological Survey Hydrologic Atlas 730-J, accessed March 17, 2015, at http:// mi.water.usgs.gov/pubs/HA/HA730-J/.

Reilly, T.E., Dennehy, K.F., Alley, W.M., and Cunningham, W.L., 2008, Ground-water availability in the United States: U.S. Geological Survey Circular 1323, 70 p. [Also available at http://pubs.usgs.gov/circ/1323/.]

Soller, D.R., 1986, Preliminary map showing the thickness of glacial deposits in Ohio: U.S. Geological Survey Miscellaneous Field Studies Map MF-1862, 1 sheet, scale 1:500,000.

Soller, D.R. and P.H. Packard, 1998, Digital representation of a map showing the thickness and character of Quaternary sediments in the glaciated United States east of the Rocky Mountains: U.S. Geological Survey Digital Data Series DDS-38, superseded by Soller and others, 2012.

Soller, D.R., Packard, P.H., and Garrity, C.P., 2012, Database for USGS map I-1970-Map showing the thickness and character of Quaternary sediments in the glaciated United States east of the Rocky Mountains: U.S. Geological Survey Data Series 656, accessed March 17, 2015, at http://pubs.usgs.gov/ds/656/.

Soller, D.R., and Reheis, M.C., compilers, 2004, Surficial materials in the conterminous United States: U.S. Geological Survey Open-File Report 03-275, scale 1:5,000,000, accessed March 17, 2015, at http://pubs.usgs.gov/of/2003/of03-275/.

Thamke, J.N., LeCain, G.D., Ryter, D.W., Sando, Roy, and Long, A.J., 2014, Hydrogeologic framework of the uppermost principal aquifer systems in the Williston and Powder River structural basins, United States and Canada: U.S. Geological Survey Scientific Investigations Report 2014-5047, 38 p., accessed March 17, 2015, at http://dx.doi.org/10.3133/sir20145047.

U.S. Geological Survey, 1985, National water summary 1984 Hydrologic events, selected water-quality trends, and groundwater resources: U.S. Geological Survey Water-Supply Paper $2275,467 \mathrm{p}$.

U.S. Geological Survey, 2002, Report to Congress - Concepts for national assessment of water availability and use: U.S. Geological Survey Circular 1223, 34 p. [Also available at http://pubs.usgs.gov/circ/circ1223/.]

U.S. Geological Survey, 2007, Facing tomorrow's challengesU.S. Geological Survey science in the decade 2007-2017: U.S. Geological Survey Circular 1309, x +70 p. [Also available at http://pubs.usgs.gov/circ/2007/1309/.]

Warner, K.L., and Arnold, T.L., 2006, Framework for regional synthesis of water-quality data for the glacial aquifer system in the United States: U.S. Geological Survey Scientific Investigations Report 2005-5223, 6 p. [Also available at http://pubs.usgs.gov/sir/2005/5223/.] 



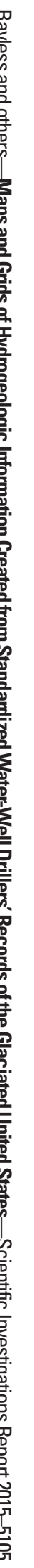

